\title{
China's Emergence and Prospects as a Trading Nation
}

CHINA's ECONOMIC REFORM and its opening to the outside world have resulted in the phenomenal growth of its output and international trade. Manufactured export growth took off after 1984, and GDP growth accelerated as well. Between 1984 and 1995, real GDP grew by 10.2 percent annually, according to official Chinese statistics. The nominal value of exports grew by 17 percent annually, while manufactured exports grew by 22 percent per year. ${ }^{1}$ The rapid growth of exports, combined with devaluation of the yuan, the Chinese currency, pushed the ratio of foreign trade (exports plus imports) to GDP from 10 percent in 1978 to 17 percent in 1984 and to 44 percent in 1994. In 1978, China accounted for only 0.75 percent of total world exports, but by 1995 , it accounted for 3.0 percent. Together, these numbers indicate the extent of China's emergence as a trading nation. ${ }^{2}$

The author is grateful for comments, suggestions, and assistance with data from Christopher Findlay, Aart Kraay, Larry Krause, Heather Smith, and, especially, Nicholas Lardy.

1. From 1980 to 1992 , the nominal value of exports grew by 13.7 percent per year, while the real value grew by 11.9 percent annually.

2. World Bank, World Development Report (1994, p. 186); China, State Statistical Bureau (SSB) (1996b, p. 105); International Monetary Fund, Direction of Trade Statistics Quarterly (September 1996, p. 2). The inadequacies of Chinese national accounts statistics should be acknowledged at the outset. Chinese GDP growth rates are overstated, primarily because of inadequate deflation. Implicit GDP deflators are lower than other relevant, consistently defined price indexes. The magnitude of overstatement probably exceeds 1 percent annually. GDP figures for all years were revised in 1995 to correct for an undercount of services. Although conceptually appropriate, this correction had the inadvertent effect of eliminating a source of offsetting bias and thus further inflated official GDP growth rates. The upward bias is partially offset by the fact that official figures do not fully account for quality improvement or for the elimination of rationing in consumption goods; because of these factors, they somewhat underestimate growth in welfare. A serious collaborative effort to recalculate Chinese GDP statistics is overdue. Trade ratios suffer not only from fluctuating exchange rates and GDP mea- 
The raw numbers are impressive, and they lend themselves to extrapolations that are even more impressive. It is natural to ask whether GDP growth rates of this magnitude can be sustained, and whether trade growth will continue to outpace GDP growth. At the outset, it should be stressed that these growth rates are not unprecedented, but in fact conform rather closely to earlier East Asian success stories. Japan's GDP grew by 10.4 percent annually between 1950 and 1973, while in both Korea and Taiwan, GDP grew at about 9 percent annually between 1960 and $1990 .{ }^{3}$ China's real distinction is its huge size and enormous population. The combination of rapid growth and large size raises a host of interesting questions. How did China achieve this economic success, and is it really as great as it appears? What difference will China's size and abundant labor force make to its future growth? What impact will China's emergence as a major trading nation have on the world trading system and on the other trading nations of Asia? This paper addresses these questions by examining China's domestic and foreign economic policies. It is based on the premise that understanding China's emergence as a trading nation requires attention both to the structural features of China's economic transformation and to the institutional details of the Chinese trading regime.

The basic message of the paper is as follows. China's achievement is real, but it has limitations that may not be immediately apparent and that will restrain growth in the future. China's export success is part of its general economic success and can be explained by the rapid pace of domestic structural change, its generally successful economic reform policies, and the proximity of preexisting export production networks, particularly those in Hong Kong and Taiwan. Over time, the growth contribution of each of these factors can be expected to diminish. While export growth will remain strong-and may continue to outpace world

surement error, but also from the intrinsic problem that trade is a gross measurement, while GDP is a net concept. Issues relating to purchasing power parity (PPP) are touched on below.

3. See Boltho and others (1994). When measurement error that inflates Chinese GDP growth is taken into account, growth in China appears to be slightly slower than in these economies. However, five coastal provinces-Fujian, Guangdong, Zhejiang, Jiangsu, and Shandong-grew more rapidly than the national average between 1984 and 1994, by at least 1 percentage point per year. These provinces had a total population of 217 million in 1994. If there is an exceptional Chinese growth story, it is the story of these five provinces. 
trade growth over the long run-it is likely to decelerate over the medium term, since the pace of structural change will slow down and China's size will tend to make the country proportionately less deeply involved in the world economy. Moreover, real appreciation and changes in policy will moderate China's heretofore spectacular reintegration with the world economy. Indeed, some of these changes have already begun. Chinese exports will post close to zero growth in 1996. And during the first half of 1996, the ratio of foreign trade to GDP had fallen to 35 percent from its peak of 44 percent in $1994 .^{4}$

The paper begins with the domestic economy, since domestic changes are of fundamental importance in shaping the national economy. The first section briefly discusses the interactions between domestic and external economic reforms. The next section reviews the fundamental domestic changes, focusing on their relation to growth and to policy options in the external sector. The following section describes the existing foreign trade and investment regimes, highlighting the creation of a dualistic trade regime characterized by parallel export promotion and import substitution regimes. Since the export promotion regime is far more liberal than the import substitution regime, the result has been to divert trade as well as to create it. Some of the quantitative dimensions of economic change are traced in this section. The next section describes recent developments in trade policy. Most important

4. Rapid changes in the ratio of foreign trade to GDP serve as a caution that this ratio should not be taken as a summary measure of "openness" that is easily comparable with other economies. In general, China's economy is less open than one might expect from looking solely at the trade ratios. Some of the reasons are discussed below. For some purposes, but not all, measures based on PPP estimates of GDP would be superior. Compared with those in other countries, the prices of nontraded goods and services in China are particularly low relative to those of traded goods. As a result, PPP calculations lead to comparatively large upward revisions in estimated GDP and large downward revisions in trade ratios. Using the World Bank's PPP estimate of 1994 per capita GDP $(\$ 2,510)$ yields a corresponding trade ratio of only 8 percent. However, such calculations lead to adjustments of roughly similar magnitudes for many other developing countries. By the same standard, India's trade ratio declines from 18 percent to 4 percent, and Indonesia's, from 41 percent to 10.5 percent. (See World Bank, World Development Report, 1996, pp. 188, 210, 216.) A definitive PPP analysis of Chinese GDP has not yet been carried out. The ratio of trade to GDP valued at exchange rates reflects actually prevailing prices and thus retains some information that is lost in the conversion to a PPP calculation. Extremely rapid changes in this ratio reflect changes both in the volume of trade and in the relative prices of goods. Thus a rapid increase in the Chinese trade ratio reflects both devaluation and rapid export growth, while a drop in the ratio reflects both real appreciation and declining exports. 
is the recent dramatic real appreciation of the currency that is severely cutting into China's export growth. I argue that this is not a short-run aberration, but rather a reflection of fundamental forces at work. The following section looks into the future, discussing five issues that will determine the pace of China's trade growth. The final section brings together the separate strands of the argument and concludes that China's integration into the world economy is likely to slow to a more moderate pace over the long term.

A number of themes run through the discussion. There have been major changes in the factors shaping the Chinese economy in the 1990s. The discussion often highlights these changes and contrasts the situation in the 1990s with that of the 1980s. In recent years, inflows of foreign investment directed toward the Chinese domestic market have become very large. As a result, policy toward foreign investment has become increasingly relevant to domestic market development and the growth of competition, as well as to financial and macroeconomic issues. Finally, regional development issues are closely related to external economic policies. In the future, a smaller share of trade growth will come from the southeastern provinces of Guangdong and Fujian than at present, and growth in trade may spread positive growth effects more broadly across China.

\section{The Relationship between Domestic and Foreign Economic Policy}

Today, domestic and foreign economic policymaking in China are inextricably interrelated, but this was not true in the earlier stages of economic reform. For the first decade or more after reform began in 1978 , foreign and domestic economic policy were made in isolation and could be analyzed separately. Early trade liberalization was cautious and gradual, and the limited degree of change was particularly striking, considering how insulated from the world economy the socialist system had been. Indeed, the essence of the initial liberalization strategy, exemplified by the creation of special economic zones (SEZs), was to set up externally oriented enclaves with minimal links to the domestic economy. Subsequently, a broader export promotion trade regime was established, but it was accessible primarily to enterprises 
with foreign investment. Even today, most Chinese firms and individuals have severely restricted access to the world market. As described below, existing institutional arrangements imply that China is significantly less open to foreign trade than initially appears.

In the 1990s, however, after a decade of sustained growth, foreign trade and investment have become sufficiently large relative to the rest of the Chinese economy that it is no longer possible to keep domestic and foreign economic policy separate. The primary cause of this increased interaction between domestic and foreign economic policy is not the elimination of trade barriers and the integration of foreign and domestic markets, but, rather, a massive inflow of foreign investment attracted largely by the opportunity of access to the Chinese domestic market. Institutional factors restrict the impact of trade on the Chinese economy, but parallel institutional factors do not necessarily reduce the impact of foreign investment on the domestic economy.

One occasionally encounters in the literature the idea that foreign investment inflows (from overseas Chinese capitalists, in particular) were in some sense engines of growth in China and crucial to the success of its economic reform success. In this view, the capital and entrepreneurship of overseas businesses seeped into China through Hong Kong and transformed the domestic economy. For the period before 1993, this view cannot be sustained. ${ }^{5}$ Rather, it should be recognized that for China as a whole, externally oriented reforms were secondary to the main progress of domestic economic reforms, and the importance of foreign trade and investment only became manifest in the 1990s, once domestic reforms had achieved substantial success. A brief look at the temporal and spatial patterns of foreign investment and trade in China can demonstrate this.

Figure 1 presents foreign investment as a share of Chinese GDP. Until 1990, foreign direct investment never exceeded 1 percent of GDP.

5. For an example of this argument, see Thomas (1991). Lardy (1995) addresses the quantitative argument, showing that net capital inflows have been modest. Externally oriented reforms have always attracted a great deal of attention in China because of their political sensitivity. The decision to establish SEZs was taken early in the reform process and represented a particularly striking departure from past orthodoxy of national selfreliance. Partly because of their high visibility, external reforms have often served as pawns in political struggles over reform policy. In addition, the largest SEZ is adjacent to Hong Kong and thus highly visible to the largest Western business and analytic community in Asia concerned with China. 
Figure 1. Foreign Direct Investment as a Share of GDP, 1983-95

Percent

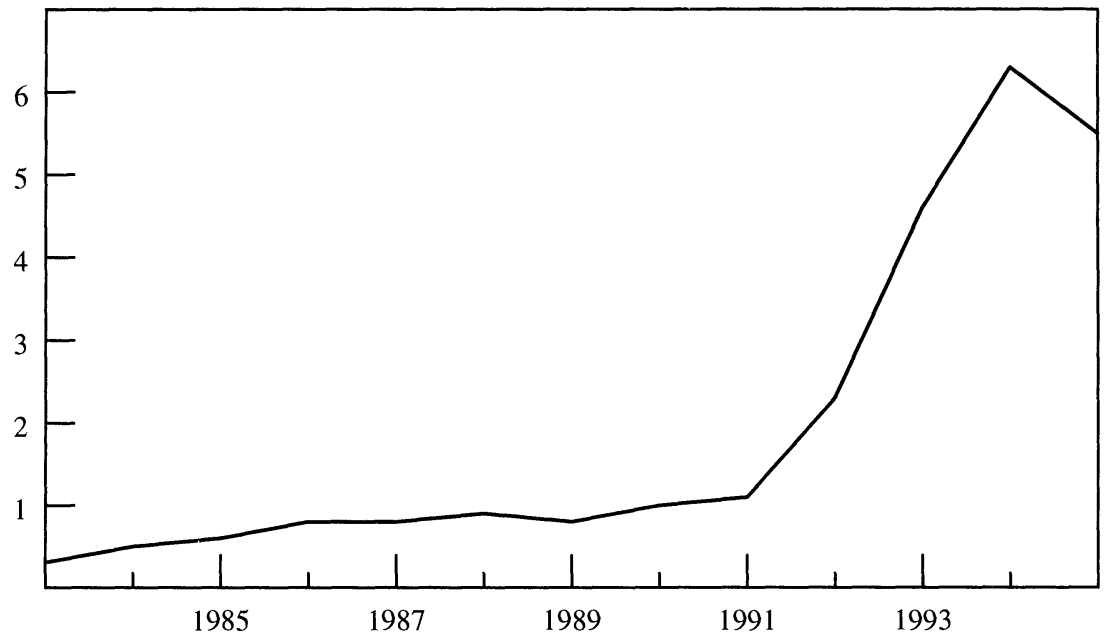

Source: China, State Statistical Bureau (SSB) (1996b, pp. 6, 106, 110).

In addition, two special circumstances limited the impact of foreign investment on the domestic economy. First, investment was geographically concentrated: slightly over a third of all foreign investment was in the province of Guangdong, adjacent to Hong Kong. ${ }^{6}$ Annual investment inflows to Guangdong, at around 5 percent of provincial GDP through the 1980s, undeniably had a significant impact on that province. However, Guangdong is a relatively small part of China; it is relatively remote from the areas that are most populous and produce the bulk of Chinese output; and it is only gradually becoming integrated into the larger Chinese economy. Therefore it was quite possible for Guangdong to be transformed by investment from Hong Kong, while the rest of China remained relatively little affected. Second, as figure 2 shows, until 1991 virtually all of the industrial output of foreign-invested en-

6. Throughout this paper, Hong Kong is treated as a sovereign entity, a source of foreign investment in China, and a destination for Chinese exports. Hong Kong data are never consolidated with those from China. After July 1, 1997, China will resume sovereignty over Hong Kong, but Hong Kong will remain a separate territory for customs purposes and is expected to maintain its own statistical system. 
Figure 2. Nominal Output and Exports by Foreign-Invested Enterprises, 1985-95a

Billions of yuan

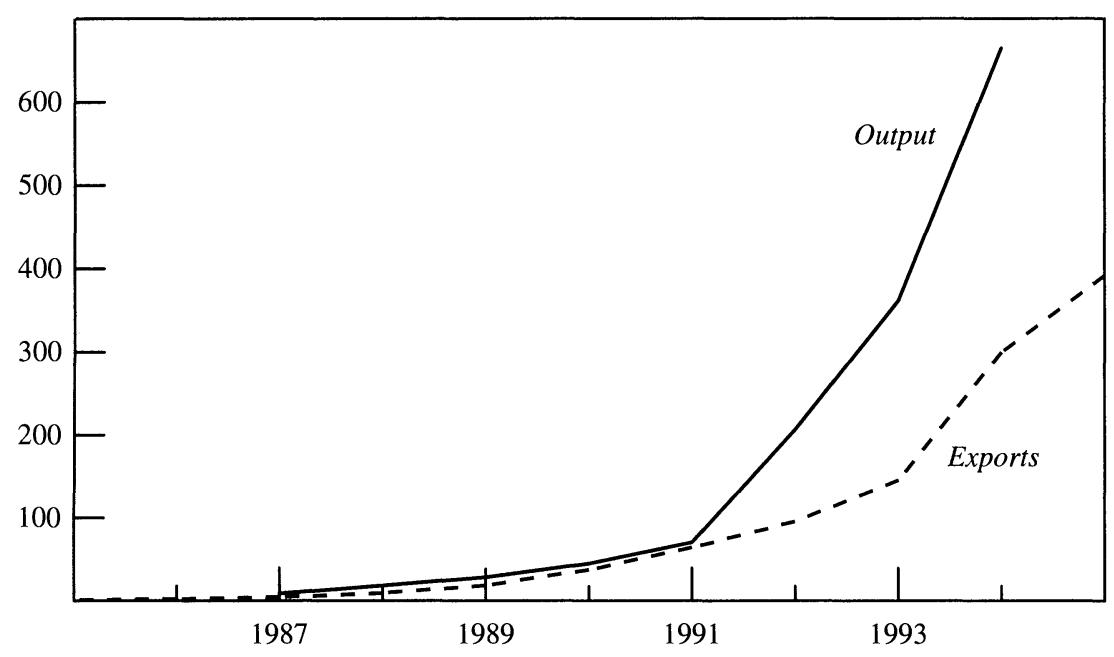

Source: Author's calculations. Output data are from China, SSB, China industrial economics statistical yearbook (various years). Export data (in U.S. dollars) are taken from World Bank (1994, p. 60) and Wang (1996) and converted into yuan using exchange rates from China, SSB (1996b, p. 106).

a. Output is defined as sales plus change in inventory.

terprises (FIEs) was exported; from which it follows that the domestic market presence of foreign firms was insignificant. ${ }^{7}$

Thus, through 1990, foreign investment was modest in size, geographically concentrated, and overwhelmingly oriented outward. In 1992 China began to offer significant domestic market access to foreign investors, particularly those who could offer "advanced technology." The definition of advanced technology was quite inclusive, and, more important, its interpretation was often left to local government officials, who were hungry for foreign investment. Investment inflows have soared past 5 percent of GDP in the years since 1993 (figure 1). They also became less concentrated geographically, although Guangdong still received a far larger proportion than any other province (inflows to Guangdong were 19 percent of provincial GDP in 1994). Since 1993, foreign investment has been as large relative to the entire Chinese

7. The two data series presented in figure 2 are from different sources and may not be strictly comparable. However, the general conclusion is not altered by any plausible adjustments. 
economy as it was relative to the economy of the single province of Guangdong in the 1980s. Moreover, FIE output has increasingly been directed toward the domestic market. As figure 2 shows, since 1992, over half of FIE industrial output was sold within China. The domestic impact of foreign investment has increased rapidly.

Today, foreign investment has an important impact on the domestic Chinese economy. But this is a relatively recent phenomenon. Massive investment inflows followed domestic economic reforms and should be analyzed in their context. Successful domestic reform in China, as in other liberalizing economies, created major new opportunities in the domestic economy. As reform progressed, these opportunities were increasingly open to foreigners. This created inflows of foreign investment, which in China overwhelmingly took the form of foreign direct investment. This sequence of events matters for two reasons. First, one of the most important policy dilemmas currently facing China is the appropriate response to large capital inflows and real currency appreciation. Second, more broadly, the strategy of domestic economic reform and the nature of domestic structural change have shaped, and will continue to shape, the pattern of China's reintegration into the world economy. Thus one can only learn so much about China's future foreign trade by extrapolating from past trends in the trade sector. One needs, in addition, to examine the structural and systemic conditions in the domestic economy that give the context for future trade development.

\section{The Domestic Economy}

Economic growth has been rapid in China primarily because of the rapid growth of productive factor inputs. And the single most important factor determining the speed of growth in the future will be the growth of factor inputs. Clearly, no economy can sustain growth rates of nearly 10 percent per year without the rapid growth of capital and labor inputs. ${ }^{8}$ In turn, labor growth at the rates required to sustain 10 percent GDP

8. This commonsensible observation is given much greater force by recent work on East Asian growth that finds that productivity growth has accounted for a modest share of total growth in the high-performing East Asian economies; see, for example, Young (1995). For further discussion, see the paper by Collins and Bosworth in this volume. 
growth can only occur during the process of structural transformation from an agrarian to a modern industrialized economy. Therefore, given China's rapid growth, one would expect China's labor force to display rapid growth and structural change, and it does. This structural change is described below. However, while the long-run rate of growth is given by saving rates and the pace of structural transformation, medium-term changes in the rate of growth are primarily determined by the impact of economic policy. In the case of transitional economies, the transition strategy dominates all other forms of economic policy. Growth in China was fairly rapid before reform, even during the turbulent Cultural Revolution period. However, China's transition strategy can be understood as the proximate cause of the acceleration in growth that occurred during the course of transition, which differentiates the Chinese case so sharply from most of the other transitional economies. Thus both structural change and transition strategy must be examined in order to understand the economic momentum and describe the trajectory of the Chinese economy in the future.

\section{Structural Transformation}

China is undergoing a rapid transformation from a predominantly rural, agricultural country to an urbanized and diversified economy. The nonagricultural labor force grew at over 5 percent per year from 1978 through 1995. Until 1991, the working age population was growing rapidly, and the agricultural labor force was growing in absolute terms, even though it was declining in relative importance. Since 1991, the growth of the working age population has slowed markedly, and agricultural employment has begun to decline in absolute numbers; its share of the total labor force will fall below 50 percent during 1997.

Labor force change is particularly dramatic in China because structural change is coinciding with extremely rapid and "precocious"' demographic change, brought about by draconian policies to curtail the birth rate. China's demographic structure is highly unusual and provides both advantages and liabilities for the economy. In a normal demographic transition, birth rates fall after the economy has reached a certain level of well-being, and life spans have increased. As a result, the share of elderly in the population begins to increase at around the time that the share of young people declines. In China, by contrast, 
birth control policies were initiated in the mid-1970s, well before the population had begun to age. Hence the share of young people in the population began to decline before the proportion of elderly had increased significantly, and the proportion of the population at working age increased. Today, both tails of the dependent population are small: the young and the old together represent a relatively small share of the population. In 1995, 67.4 percent of the population were between the ages of fifteen and sixty-four (as compared with 57 percent for all other low-income countries and 61.5 percent for all middle-income countries). Moreover, the proportion of the population at working age will actually increase until about 2010 , when it will surpass 71 percent. ${ }^{9}$ Such an age structure has both tangible and intangible benefits. Lower dependency ratios imply higher material living standards for any given level of worker productivity. And a young population is more adaptable and able to accept the rapid social changes that accompany the shift to a market economy.

Because of these demographic changes, over the past twenty years the working age population has grown extremely rapidly in absolute terms, and significantly more rapidly than the population as a whole. During the $1980 \mathrm{~s}$, the working age population grew by 2.5 percent per year. Conversely, the labor force is growing much more slowly today, due to the much smaller entering cohorts-those born after the late 1970s, when the birth control policies had fully taken hold. In the future, growth will slow further. Table 1 summarizes the basic facts on labor force growth since 1978 and projected to 2025. The first two rows show the long-run decline in labor force growth. The third row shows trends in the agricultural labor force and highlights the changes that began in 1991. The growth of the nonagricultural labor force growth has been rapid throughout. Service sector employment has outpaced industrial employment, markedly so since 1991, when it has grown by more than 8 percent annually. Table 1 also shows plausible future labor force trends. These are designed to bring out the relationship between different variables, some of which can be known with a fair amount of

9. Unpublished 1996 projections of the Chinese population are from U.S. Bureau of the Census, International Data Base. I am indebted to Loraine West for providing the data and taking the time to explain them thoroughly, and to Christina Harbaugh and Judith Banister for providing details of the methodology used in the projections. International comparisons are from World Bank, World Development Report (1994, p. 210). 
Table 1. Growth of Labor Force, by Component and Subperiod, 1978-2025

Annual percentage rate

\begin{tabular}{lcrrrr}
\hline Component & $1978-91$ & $1991-95$ & $1995-2005^{\mathrm{a}}$ & $2005-15^{\mathrm{a}}$ & $2015-25^{\mathrm{a}}$ \\
\hline Working age population $^{\mathrm{b}}$ & 2.5 & 1.2 & 1.3 & 0.7 & 0.0 \\
Total employment & 2.9 & 1.2 & 1.3 & 0.7 & 0.0 \\
Agricultural employment & 1.6 & -2.1 & -2.1 & -2.1 & -2.1 \\
Nonagricultural employment & 5.4 & 5.0 & 4.1 & 2.2 & 0.7 \\
$\quad$ Industry & 4.6 & 3.1 & $\ldots$ & $\ldots$ & $\ldots$ \\
Services & 6.5 & 8.4 & $\ldots$ & $\ldots$ & $\ldots$ \\
\hline
\end{tabular}

Source: Author's calculations. Labor force data used to calculate growth for 1978-91 are from China, SSB (1995b, pp. 84-85); and for 1991-95, from China, SSB (1996b, p. 21). Projected growth of the working age population, 1995-2025, is supplied by the U.S. Bureau of the Census from its International Data Base. Employment projections are based on the projected growth rate of the working age population and the following two assumptions: that labor force participation rates will not change, and that agricultural employment will continue to decline by 2.1 percent annually until 2020 and will then level off.

a. Projected.

b. Ages fifteen to sixty-four.

confidence. Given the existing age structure and assuming that agespecific fertility rates remain constant, the working age population will continue to grow at 1.3 percent annually for only about a decade. After 2005 , growth will slow down quickly, and there will be zero growth after 2015. Further, assuming that labor force participation remains unchanged and (crucially) that agricultural employment continues to shrink by 2.1 percent annually, the growth of nonagricultural employment will slow down slightly, to 4.1 percent, in the next decade and continue to fall, reaching 2.2 percent per year in the subsequent decade and only 0.7 percent annually between 2015 and 2025. ${ }^{10}$

While labor force growth was an important source of growth in output, Chinese reformers saw the need to create millions of new jobs annually as a heavy burden. A recently popular interpretation of China's transition experience is that the abundant labor supply was an important advantage, enabling China's gradualist reform strategy to succeed by

10. While these numbers represent only one possible scenario, it is hard to argue that others are more plausible. Fertility might increase if government social control were to decline or if a government with significantly different preferences were to come to power. This is possible but is not the most likely prospect. Agricultural employment might decline more slowly if the country were to face serious economic difficulties, and this would further slow the growth of nonagricultural employment. Declining at 2.1 percent annually, the agricultural labor force will have fallen to 23 percent of the total labor force by 2025 . A slightly faster decline is also conceivable, but 2.1 percent per year is a plausible midrange estimate. 
ensuring the necessary supply of labor and entrepreneurship for new start-up businesses. ${ }^{11}$ Whether or not that is true in retrospect, rapid labor force growth was certainly seen as a constraint by Chinese policymakers at the time. They constantly complained that China's surplus labor forced them to tolerate (and even create) make-work jobs and to rule out more dramatic reform measures that might increase productivity rapidly at the cost of sharp short-run increases in unemployment. Until the 1990s, policymakers considered it the responsibility of the public sector to provide employment for all urban job-seekers and for many of the surplus agricultural workers.

Figure 3 shows the creation of jobs by different ownership forms over the period 1978-95. During the subperiod 1978-86, employment growth occurred primarily in agriculture (private), community-owned township and village enterprises (TVEs), and the urban public sector, which comprises state-owned enterprises (SOEs), urban collectives, and government employment. ${ }^{12}$ Community-owned TVEs and the urban public sector created two-thirds of net new nonagricultural employment

11. See, for example, Sachs and Woo (1994) and World Bank, World Development Report (1996). It is certainly true that China is abundantly endowed with labor and entrepreneurship. Yet one wonders whether supplies of labor and entrepreneurship in eastern Europe and the former Soviet republics really were sufficiently inelastic that the healthy growth of start-up businesses was impossible under gradualist transition strategies. If so, this would contrast sharply with the widespread observation that in nearly all the formerly socialist countries, the growth of the new private sector has surpassed expectations and has been one of the major successes of transition.

12. My classification of ownership differs from the usual presentation of the Chinese data. I adapt official Chinese data slightly in order to eliminate the effects of inconsistent data collection and some misleading categories. In the Chinese statistics, TVE employment includes firms run by community (township and village) goverments and also many rural private firms. However, the coverage of private employment is inconsistent: all rural private firms are classified as TVEs in the mid-1980s, but some are separated out as non-TVE private firms in the 1990s. I use here an intertemporally consistent and more meaningful subset of the official classification: employment in TVEs "at the township or village level"; that is, in community-owned firms. Firms that are counted in the official statistics as TVEs, but are private or are run jointly by cooperating households, I consider to be in the private sector. My urban public sector category explicitly aggregates government employment, SOEs, and so-called urban collectives that are generally dependent on SOEs or local governments (see Naughton, 1995, pp. 165-66). One advantage of this classification is that "private" really means private-it does not include any collectives or government-sponsored employers. There is no omnibus nonstate category. SOEs that have been transformed into joint-stock corporations are considered to remain in the urban public sector, since the government continues to own a controlling interest in virtually all of them. 
Figure 3. Employment Growth by Type of Firm Ownership and Subperiod, 1978-95

Annual employment change (millions)

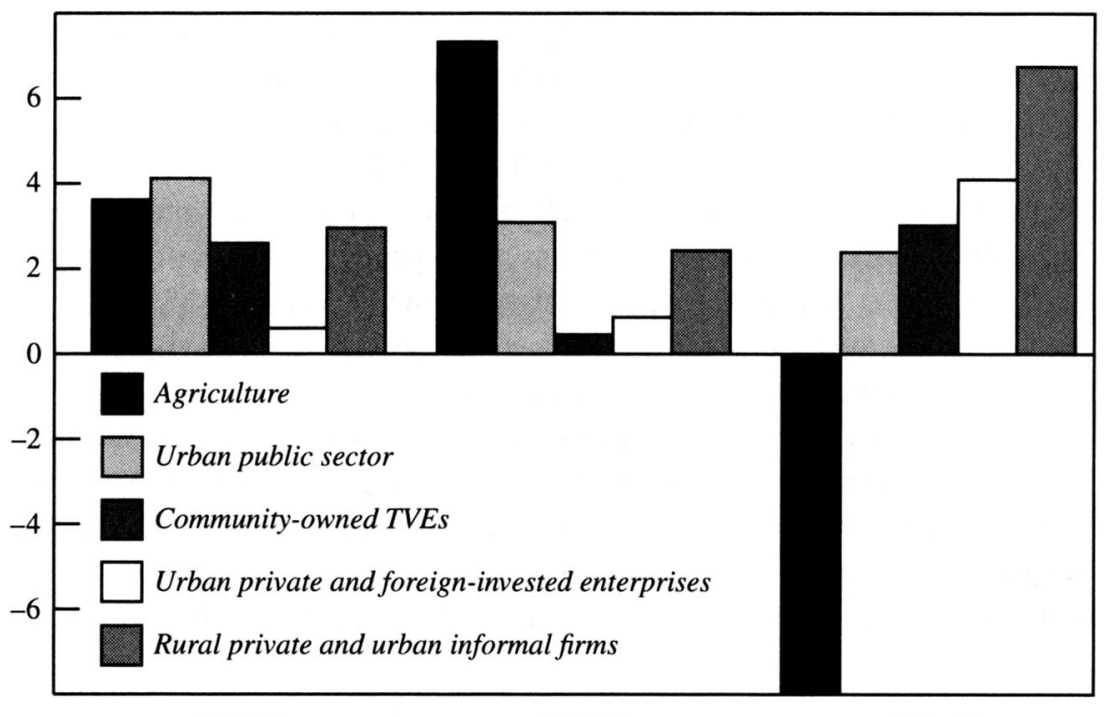

$1978-86$

$1986-91$

$1991-95$

Source: Author's calculations based on data from China, SSB (1995b, 1996b).

in this subperiod. In the 1986-91 subperiod, due to the economic slowdown and a conservative backlash against TVEs, this share dropped, but it did not fall below 50 percent. The pattern of labor absorption changed dramatically after 1991 . The number of new nonagricultural jobs more than doubled from that in the 1986-91 subperiod. However, the number of new jobs created in the urban public sector declined. Employment in community-owned TVEs recovered, but even so, the public sectors together created only about a third of all new nonagricultural jobs. Private sector employment growth jumped from 3.46 million new jobs per year in 1986-91 to 10.85 million annually in 1991-95. Moreover, every part of the private sector participated: rural private sector jobs formed the largest component, and foreign-invested enterprises generated 890,000 jobs a year. Yet despite rapid growth in output, as the pace of restructuring accelerated, registered urban unemployment increased by 420,000 persons a year, reaching a total of 5.2 million by the end of 1995 . 
Thus China is at a structural turning point. The economy has already moved from a period of very rapid labor force growth to one of much slower labor force growth. In a sense, this relieves the public authorities of some of their perceived responsiblity, and they are now allowing themselves to reduce the role of public sector employment. But with growth in nonagricultural employment slowing from the current rate of 5 percent a year to only 0.7 percent a year in 2015-25, one would expect Chinese growth rates to decline as well. Under normal assumptions about output elasiticities and relative productivity in the agricultural and nonagricultural sectors, output growth should decline by more than 2 percentage points. ${ }^{13}$ Moreover, as growth of the working age population slows to zero, the population share of the elderly will increase. The share of the population over age sixty-five will increase from 6.1 percent in 1995 to 13.9 percent in 2025 . At that time, the economy will have a heavy social security burden (which may cause the government to levy higher taxes, possibly further retarding growth), and will have a somewhat older, arguably less adaptive or flexible work force.

\section{Market Transition}

China's domestic reform strategy is crucial to its international economic policy for a number of reasons. First, the approach to external policy reform has mirrored the approach to domestic reform: gradual change, dualistic economic systems with parallel pricing, decentralization, emphasis on the entry of new producers and traders alongside existing (reformed) public agents, and the desire (not always realized) to keep ultimate control in the hands of the central government. ${ }^{14} \mathrm{Sec}-$ ond, the specific achievements and limitations of earlier domestic re-

13. With an output elasticity of 0.6 in both the agricultural and the nonagricultural sectors, and with an agriculture labor share of 0.5 and a GDP share of 0.2 in 1985, the numbers in table 1 imply a labor contribution to growth averaging 2.8 percentage points per year between 1978 and 1991. By 2020, agriculture's share of labor will be down to 0.19 . Its output share will depend on changes in relative productivity and relative prices. Using plausible estimates, the output share may range from a low of 0.04 to an unchanged 0.2. This implies that labor's contribution to growth will decline to between 0.4 and 0.1 percentage point per year for the period 2015-25. I do not deal separately with capital accumulation and saving rates because there seems no sensible assumption other than that saving rates will remain quite high.

14. Harrold (1995). See also Naughton (1995). 
forms determine what is possible in external policy reform today. In particular, the concerns about stability and employment mentioned above caused Chinese policymakers to adopt an approach to economic reform that postponed many hard choices. Early in the reform process, the government implemented policies that contributed to employment growth and increasing living standards, but also cushioned existing enterprises from the increase in competition that a market transition inevitably implies. Although many of those policies were successful, they have created a legacy of deferred problems that could constrain action today. The economy is now larger and far more resilient than at the start of the reforms, and policymakers have more experience and access to greater economic management expertise with which to deal with these challenges, but that is no guarantee that they will be overcome. This legacy is of particular relevance to the external sector, where the government's ability to insulate domestic individuals and enterprises from difficult economic change is limited by world market forces.

MARKET CHANGE. Chinese transition strategy has relied on the creation of market competition through the entry of new domestic producers. There has been some privatization of existing (mostly small) SOEs, but this has not been a major force behind structural changes in ownership. Instead, policy has been favorable to a range of new entrants, facilitating first township and village enterprises and subsequently, private and foreign-invested firms. As a result, the share of traditional state-owned enterprises in total industrial output has declined steadily from 78 percent in 1978 to only 31 percent in $1995 .{ }^{15}$ While this process has succeeded in creating a diversified and competitive national industrial base, domestic firms remain largely protected from international competition. Domestic market competition has increased steadily, but within limits.

The change in the pattern of labor absorption away from public enterprises (in the 1980s) and toward the private sector (in the 1990s) has been documented above. A parallel shift from public to private can be traced in industrial output. During the 1980s, the crucial role in the creation of competition was played by publicly owned TVEs. From an output share of 8.7 percent in 1978, TVEs increased their share to over

15. China, SSB (1996b, p. 75). 
20 percent in 1990. At this time, the output share of FIEs was still less than 2 percent, and virtually all of this was exported. However, in the 1990s, FIEs began to take the lead in domestic competition. The breakdown of ownership composition of industrial output for 1994 (detailed figures for 1995 are not yet available) is as follows: ${ }^{16}$

Ownership type

Total state and commercialized state

State

Shareholding

Unclassified

Total collective

Urban

Township

Village

Total private and household

Joint household

Private

Total foreign-invested

Hong Kong, Macau, and Taiwan

All other countries
Percent of industrial output

39.0

34.1

3.9

1.1

37.5

7.0

14.8

15.7

14.9

3.4

11.5

8.6

4.1

4.5

Total FIE output had soared to 8.6 percent of total output by 1994 , a substantial proportion of which was available for the domestic market. Foreign investors, once they have overcome the hurdles to entry, enjoy very substantial protection in the Chinese market-the same protection from imports as is offered to domestic firms. Foreign companies have rapidly developed commanding presences in a number of product lines: for example film (in which they have a market share of over 80 percent), passenger cars, certain heavy chemicals (with a market share of over 50 percent), laundry detergent, and carbonated beverages. ${ }^{17}$

Today, while SOEs exist in all industrial sectors, they are relatively concentrated in a small number. In 1994, state-owned enterprises pro-

16. China, SSB (1995b, pp. 375, 380-81).

17. “Chinese Trademarks: Endangered?' China News Analysis, May 15, 1996, p. 8. 
duced about two-thirds of total output in resource extraction and utilities. Within manufacturing, SOEs are concentrated in six heavy industrial and chemical sectors, as well as cigarette manufacturing. Taken together, these account for a majority (53 percent) of state sector output. ${ }^{18}$ By contrast, these same sectors account for less than 20 percent of nonstate output. Thus the gradual increase in competition has pushed SOEs into sectors in which they are protected from the full force of competition either by monopoly or by technological barriers to entry. However, the growth of FIEs is now eroding the latter protection. Overall, the Chinese gradualist approach to reform maintained the state sector as a source of stability that also provided key natural resources, infrastructure services, and output in hard to reform capital-intensive sectors. This approach fostered a positive environment for new startup businesses, which have steadily grown in importance. It was possible for the economy to "grow out of the plan." ${ }^{19}$ Eventually, this positive environment became a key factor in encouraging inflows of foreign direct investment.

FINANCIAL AND FISCAL EVOLUTION. Figure 4 presents the evolution of China's budgetary expenditures. Since formal budget deficits were less than 2 percent of GDP throughout the period shown, the expenditure trends can also shed light on revenue trends. Figure 4 thus displays a remarkable record: China's budgetary expenditures have consistently declined as a share of GDP from a peak of 37 percent in 1979 to 13 percent in 1995. Other transitional economies have also experienced significant reductions in fiscal weight-in eastern Europe, the average decline in the revenue share in GDP between 1989 and 1991 was 10 percentage points, which was followed by a further 3.5 percentage point decline in $1993 .{ }^{20}$ China has never experienced such a dramatic short-term drop. But conversely, the decline in China's revenue has been much more protracted than that of any other country. Moreover,

18. China, SSB (1995b, pp. 375, 388, 392, 399). Data on the sectoral composition of industrial output by ownership form are available for SOEs, TVEs, and a category called "other," which comprises foreign-invested enterprises, urban collectives, and joint-stock corporations. These ownership categories produced 82 percent of total output in 1994. Data are not available on sectoral compostition for private and joint household firms, which produced most of the remaining output.

19. Naughton (1995).

20. Bélanger and others (1994). 
Figure 4. Composition of Budgetary Expenditures, 1978-95

\section{Percent of GDP}



Source: Author's calculations based on data from China, SSB (1995b, pp. 216-19; 1996b, p. 40), adjusted for comparability across years; for details, see Naughton (1995, pp. 337-39).

the revenue ratio has declined to extremely low levels, relative to those of other countries. ${ }^{21}$

Figure 4 also shows how the government has dealt with declining revenues. Investment outlays have shrunk dramatically, from over 15 percent of GDP in 1978 to 2.2 percent in 1995. Subsidies to SOEs (including industrial, grain supply, and foreign trade) initially ballooned to 8 percent of GDP in the early 1980s, but had been cut to 1.2 percent by 1995 . The government has attempted to protect civilian

21. Chinese budgetary figures are not fully comparable with those of other countries. For example, social security payments for retired SOE workers amounted to 1.9 percent of Chinese GDP in 1994, but these were paid either by the enterprise or by newly established provincial social security funds; social security payments are not currently included in budgetary revenues or outlays. Certain types of earmarked taxes are placed in the broad and heterogeneous category of "extrabudgetary funds," rather than being listed as fiscal revenues. Even after adjustment for these idiosyncrasies, there is no doubt that the erosion of budgetary revenues and expenditures has become extreme, by comparative standards. 
current outlays and, to a lesser extent, military outlays. However, despite the cuts in investment and subsidy outlays, these core functions are under great pressure. Civilian current outlays had generally been kept at around 10 percent of GDP through the 1980s, but by 1995 they had declined to 8.4 percent, the lowest recorded level. This is evidence of a serious fiscal crisis. ${ }^{22}$

Particularly surprising is the continued decline in the revenue share after 1993. China implemented a broad and comprehensive fiscal reform, effective January 1, 1994. The crucial features included unification of income tax rates on enterprises with different ownership systems, a shift to a broad-based 17 percent value-added tax (VAT), and creation of a national tax collection agency. This reform ought to have halted the erosion of fiscal revenues. The fact that it has not shows that the problem is deep seated, grounded in loss-making SOEs, local governments with the power to grant a variety of tax breaks, the difficulties of taxing the growing small-scale sector, and delays in creating an effective national tax service that is completely independent of local governments.

STRUCTURAL CHANGE IN OWNERSHIP, FISCAL DECLINE, AND THE FINANCIAL SYSTEM: THE ROLE OF THE SOES. The changes in the government's fiscal position are intimately related to the changing role of the SOEs and the government's policy toward new entrants to the domestic market. Before the reforms, China relied on industrial SOEs to provide more than 80 percent of budgetary revenues. Local governments served as the primary tax collectors, harvesting surpluses from "their" enterprises and turning revenues over to the central government. In 1978 the industrial SOEs turned over fully 25 percent of GDP to the government in profits and taxes. In subsequent years this surplus has been steadily reduced. Competition from TVEs, FIEs, and other state enterprises has eliminated the monopoly position of the SOEs. Their profits have steadily declined as a share of GDP, and, in addition, they now retain a healthy share of their total profits. The number of loss-making SOEs, once insignificant, is large and growing. Moreover, as profitability has declined, local governments have colluded with local enterprises to

22. There is some evidence that health standards declined in some of China's poorer provinces during the 1990s. This seems to reflect cutbacks in government public health programs in those regions. 
Table 2. Composition of Public Sector Deficits, 1987-95

Percent of GDP

\begin{tabular}{lccc}
\hline & \multicolumn{3}{c}{ Public sector deficit } \\
\cline { 2 - 4 } Year & Budget $^{\mathrm{a}}$ & State enterprises & Total \\
\hline 1987 & 2.1 & 8.6 & 10.7 \\
1988 & 2.4 & 8.3 & 10.7 \\
1989 & 2.3 & 9.1 & 11.4 \\
1990 & 2.2 & 10.1 & 12.3 \\
1991 & 2.5 & 8.5 & 10.9 \\
1992 & 2.6 & 10.5 & 13.1 \\
1993 & 2.3 & 10.3 & 12.7 \\
1994 & 1.7 & 8.2 & 9.9 \\
$1995^{\mathrm{b}}$ & 1.7 & 7.0 & 8.7 \\
\hline
\end{tabular}

Source: World Bank (1996, p. 11).

a. All government spending, except that of state-owned enterprises.

b. Estimated.

keep a greater share of revenues out of the hands of the central government. The result has been steady erosion of budgetary revenues.

The government still extracts significant surpluses from the SOE sector. Two-thirds of fiscal revenues came from SOEs in 1994 (down from 85 percent in 1978). ${ }^{23}$ While many individual SOEs run losses, the industrial SOE sector as a whole still has substantial net accounting profits. Moreover, the apparent tax rate on SOEs is significantly higher than that on TVEs, FIEs, or private firms. Yet despite the apparent current cash flow surpluses, the SOEs run huge deficits on their investment accounts. ${ }^{24}$ In order to ensure both that SOEs can continue to contribute to budgetary revenues and that the government's priority investment projects reach completion, the government requires the banking system to provide credit to SOEs. Bank credit indirectly provides revenues for the government, and it has replaced budgetary expenditures as the primary source of financing for state sector investment. A recent World Bank report on the Chinese economy summarizes these trends. ${ }^{25}$ As table 2 shows, the SOE sector has had large net deficits (including investment flows) since the late 1980s. SOE deficits

23. One half of budgetary revenues comes from the industrial sector. One can speculate that the larger part of these come from SOEs, but no cross-classifications are available for budgetary revenues.

24. By contrast, before the reforms industrial SOEs had a large net surplus, even accounting for investment grants; see Naughton (1992).

25. World Bank (1996). 
peaked at over 10 percent of GDP in 1992-93, and with a budget deficit of slightly over 2 percent in those years, the aggregate public sector deficit was around 13 percent of GDP.

Most of the financial deficit of the SOE sector funds investment, so it should not be presumed that the optimal deficit for the sector is zero. It is common for the business sector to run a long-term financing deficit with the household sector in a market economy, and it may be appropriate for Chinese SOEs to run a long-term deficit as well. But under Chinese conditions, there is substantial reason to believe that the present deficit is too large. The government directs fixed investment credits toward priority SOE projects, many of which do not have high enough rates of return to justify the lending. The result has been a steady increase in SOE debt and a deterioration in the quality of bank balance sheets. Fortunately, household saving remains strong and provides continued infusions of loanable funds to the banking system. But the danger of default and financial crisis is not insignificant. Government pressure on the banking system amounts to a very substantial hidden tax on the system and, ultimately, on depositors. By controlling interest rates and maintaining high reserve requirements, the government holds down returns to the banking system, and so banking sector profitability is deteriorating. More critical, returns to depositors are low, particularly when inflation accelerates. Indeed, over the past fifteen years, the banking system has faced at least three crises in which significant funds were withdrawn, forcing the government to inject reserves into the system, increase deposit rates to a real rate of zero, and restrict financial options outside the banking system. In consequence, the government holds back from essential financial reforms because of fears that liberalization will cause the weakened banking system to collapse.

Thus changes in ownership composition, fiscal decline, and the fragility of the financial sector are closely related, linked together by the changing - and problematic - role of the SOEs. Existing policies have fostered growth throughout the 1980s and 1990s by allowing market entrants to reap, and eventually compete away, monopoly rents that had previously been reserved for the state sector. Moreover, low effective tax rates on nonstate firms have encouraged new entrants, including FIEs. At the same time, fixed investment, including infrastructure spending, has been sustained at fairly high levels. In 1995 fixed investment amounted to 34 percent of GDP, slightly over half of which 
(54 percent, or 19 percent of GDP) was investment by SOEs. Continued high investment was a major contributor to growth throughout the 1980s and 1990s and indirectly facilitated the growth of nonstate producers as well as state firms. But such policies came at the cost of extreme, and arguably increasing, financial fragility.

Currently, competitive pressures on SOEs are intense, and unemployment is increasing, notwithstanding the rapid growth of output. Table 2 shows that the SOE deficit shrank in 1994 and 1995, following the adoption of austerity policies in mid-1993. ${ }^{26}$ These policies have substantially curtailed the access of SOEs to guaranteed credit, and, striving to cut costs, SOEs have cut back employment in open and hidden ways. By the end of 1995, registered urban unemployment had reached 5.2 million, approaching a rate of 3 percent. In addition, a large number of state workers nominally have jobs but have been sent home with reduced (or no) pay, because the enterprises have no work. This year, for the first time, the State Statistical Bureau has provided a number for workers in this category: 7.25 million at the end of March 1996, which is significantly higher than registered unemployment. Together, the numbers imply that 7 percent of the urban work force lacks gainful employment. ${ }^{27}$ This figure is quite high by Chinese standards and explains why the Chinese government is worried about the pace of restructuring in the urban economy.

The interrelated financial difficulties of the government budget, the SOE sector, and the banking system define the constraints on policymakers. Obvious measures to increase the financial health of any one of the three sectors are complicated, perhaps made impossible, by their potential impact on the other sectors. This situation is particularly relevant to the progress of external economic reform. Rapid import liberalization would greatly increase competitive pressure on certain sectors, particularly capital- and technology-intensive heavy industries. This would certainly increase the rate of SOE failure and could dramatically increase the rate of bankruptcy. Accelerated SOE failure

26. Nicholas Lardy has brought to my attention figures showing that the reduction in the SOE deficit in recent years may be less than the World Bank figures indicate and may even be insignificant. This would indicate that the current troubles in the SOE sector are still more deep seated, since fewer of the losses could be attributed to a necessary tightening of budget constraints.

27. China, SSB (1996a; 1996b, p. 24). 
would increase unemployment and also expose the weaknesses in bank balance sheets, perhaps precipitating a financial crisis. Similarly, greater capital account liberalization might lead to financial crisis if Chinese citizens are given the option to transfer funds on a large scale from the domestic banking system to other-especially internationalassets.

\section{Foreign Trade and Investment}

China, like other planned economies, embarked on the process of transition with a highly centralized, monopolistic foreign trade regime. Control over international transactions was extremely tight, characterized by overlapping controls on both the flow of goods and the flow of money. All import and export decisions were made administratively, and the desire to insulate the domestic economy from the influence of world prices was an important consideration in determining which transactions to allow. Since 1978, China has gradually but systematically dismantled this web of administrative controls and established a system in which most trade is governed by market forces. ${ }^{28}$ By about 1986, the government had fundamentally transformed the rules of foreign trade and investment, largely dismantled the foreign trade monopoly, and created the conditions that made possible the subsequent spectacular growth of trade and investment. In that sense, China's external reforms have undeniably been successful. Nevertheless, these policies have certain inherent limitations. There is a very great distance between a command economy trading system and an open trade regime: China has traveled much of this distance, but it still has a long way to go. While I frequently stress the limitations of present policy and the challenges for the future, it should be recognized that such challenges arise in the context of substantial achievement in earlier reforms.

The main elements of trade reform to date have included:

-Devaluation. This policy was an obvious prerequisite of successful trade reform. By 1987, the real exchange rate was below 50 percent of its 1980 level. As figure 5 shows, China's devaluation ultimately co-

28. The process of policy reform has been well described elsewhere; see, for example, Lardy (1992a, 1992b, 1995), Fukusaku and Wall (1994), Howell (1993), Harrold (1995), and World Bank (1994). 
Figure 5. Nominal Exchange Rates of Currencies of Selected Asian Countries against the Dollar, 1980-95

Index, $1980=100^{\mathrm{a}}$



Source: International Monetary Fund, International Financial Statistics (various years).

a. Based on price of local currency in dollars, so that an increase represents an appreciation of the local currency.

incided with the realignment of nominal currency rates throughout East Asia. The Japanese yen appreciated markedly after 1985 , followed by the new Taiwanese dollar in 1986. The Chinese yuan and the Indonesian rupiah depreciated substantially against the dollar and even more dramatically against the stronger Asian currencies. This set the scene for the restructuring of output and trade in subsequent years.

- Relaxing restrictions on convertibility. Starting from inconvertibility, important steps have been taken toward making the Chinese currency fully convertible. Exporters were allowed to retain initially small but increasing percentages of their export earnings. In 1986 a dual exchange regime was instituted: select enterprises (including most of the FIEs) were given access to a "swap market," in which Chinese domestic currency was traded for foreign exchange, usually at a signif- 
icant discount relative to the official rate. On January 1, 1994, the official rate was again devalued, and the exchange rate was unified at close to the swap market rate. Since then, the currency has been on a managed float, and the government trades foreign exchange through a network of authorized foreign exchange banks. Today, access to these banks is open to all registered entities with foreign trade rights, upon presentation of the required documentation. Full current account convertibility is expected by the end of 1996 .

-Demonopolizing the foreign trade regime. From twelve national monopoly corporations, the number of foreign trade corporations (FTCs) had grown to 5,075 by 1988 . Provincial subsidiaries of the national corporations were set up as independent companies, and new FTCs were created. Direct export and import rights were also granted to some manufacturing enterprises. Between 1992 and the end of 1995 , the number of production enterprises with trade rights expanded rapidly from a few hundred to 3,400 , and the total number of domestic firms with import or export rights is now close to $10,000 .{ }^{29}$

-Reducing nontariff barriers. Under the old system, all imports and nearly all exports were planned. In that sense, virtually all trade was covered by nontariff barriers (NTBs). Administrative controls and nontariff barriers have now been substantially reduced, although not eliminated.

- Changing pricing principles. Imports are increasingly priced according to the agency system, in which domestic prices equal the world price plus a commission paid to the importer. Formerly, all imports were converted into domestic price equivalents. Exporting trade corporations continue to procure export supplies on their own account, but increasingly have to compete with other FTCs.

These steps have established the essential conditions for China's successful trade performance. Indeed, the coincidence of rapid export growth and apparently successful policy reform has led some observers to believe that China is another example of export-driven development success, following on the heels of the other high-performing Asian economies. This view is not totally mistaken, but it misses many of the unique characteristics of the Chinese process. In fact, to a far greater

29. China Economic News, June 24, 1996, pp. 16-17. 
extent than is reflected in the literature, China's success with exports has been dependent on its dualistic trading regime, as well as on the intensive participation of foreign investors.

Building on the policy reforms listed above but, in a sense, more important than any of them, is one final element of reform: the creation of a separate, export-promoting trade regime for foreign-invested enterprises. This concessionary regime bypasses the centralized foreign trade monopoly and its successor institutions. It is highly open to the outside world and operates with a minimum of administrative and other restrictions (after the initial approval process). Goods are imported and exported with very little administrative interference, usually without tariffs, and with the benefit of a variety of tax concessions. The enterprises operating under this regime have been the most impressive contributors to Chinese export growth.

By 1986-87, China had established, in essence, two separate trading regimes. One is an export processing or export promotion (EP) regime. Although it is extremely open, access is controlled: most domestic firms are excluded, while most foreign-invested firms can participate. The other is the traditional, but increasingly reformed, Chinese regime, which is basically an import substitution regime. Following Chinese terminology, I label this the ordinary trade (OT) regime. Both regimes are discussed below. At the outset, though, consider the magnitude of the disparity between the number of enterprises qualified to participate in each: "Close to 10,000 [domestic] enterprises have been given trading rights, and all the 259,000 approved foreign-invested enterprises are allowed to handle foreign trade within a prescribed scope." ${ }_{30}$ More than twenty-five times as many firms operate in the EP regime than in the OT regime.

\section{The Export Promotion Regime}

Two elements were crucial to the creation of the export promotion regime in China. The first was the development of an approval procedure, a legal framework, and concessionary taxation policies that encouraged foreign investors to establish export-oriented firms in China. The second was the establishment of a program of export processing,

30. Sun Zhenyu (vice minister of foreign trade), "The Present State of China's Foreign Economic and Trade Situation,"' China Commercial News, August 1996, p. 33. 
Table 3. Total Exports and Exports by Foreign-Invested Enterprises, 1985-96

Billions of dollars, except as indicated

\begin{tabular}{lccc}
\hline & & \multicolumn{2}{c}{ Foreign-invested enterprises } \\
\cline { 3 - 4 } Year & Total exports & Exports & $\begin{array}{c}\text { Share in } \\
\text { total exports }\end{array}$ \\
\hline 1985 & 27.4 & 0.3 & 1.1 \\
1986 & 30.9 & 0.6 & 1.9 \\
1987 & 39.4 & 1.2 & 3.1 \\
1988 & 47.5 & 2.5 & 5.2 \\
1989 & 52.5 & 4.9 & 9.4 \\
1990 & 62.1 & 7.8 & 12.6 \\
1991 & 71.9 & 12.0 & 16.8 \\
1992 & 85.0 & 17.4 & 20.4 \\
1993 & 98.0 & 25.2 & 25.8 \\
1994 & 121.0 & 34.7 & 28.7 \\
1995 & 148.8 & 46.9 & 31.5 \\
$1996^{\mathrm{b}}$ & 64.1 & 26.2 & 40.8 \\
\hline
\end{tabular}

Source: China, SSB (1995a, p. 164); China, General Administration of Customs (GAC), China Customs Statistics (1994:12, p. 19; 1995:12, p. $20 ; 1996: 4$, p. 21 ).

a. Percent.

b. Numbers refer to first six months.

under which inputs and components needed for the production of goods for export were imported duty free, with a minimum of administrative interference. The importance of foreign investment in the growth of China's trade has been widely recognized. ${ }^{31}$ Table 3 shows the rapid growth of both total Chinese exports and exports generated by foreigninvested enterprises. During the first half of 1996, FIEs generated 41 percent of China's total exports. Perhaps less frequently appreciated is the extent to which these FIEs have operated under an entirely different set of institutions and regulations than applies to most domestic enterprises.

The most important of these institutions is the duty-free processing of imported materials and components into exports. Two variants of this policy are in effect today. The first type of duty-free processing trade (lailiao jiagong) - referred to as outward processing in Hong Kong, and here, as processing materials - takes place under a contract in which a foreign business, usually located in Hong Kong, ships materials to Chinese enterprises for processing or assembly and subsequent

31. See, for example, Lardy (1992b, 1995), Pomfret (1991), and La Croix, Plummer, and Lee (1995). 
Table 4. Imports under Concessionary Terms and Processed Exports

Percent of total ${ }^{\mathrm{a}}$

\begin{tabular}{|c|c|c|c|c|c|c|}
\hline Concession regime $e^{\mathrm{b}}$ & 1988 & 1991 & 1993 & 1994 & 1995 & $1996^{\mathrm{c}}$ \\
\hline \multicolumn{7}{|l|}{ Exports using concessionary imports } \\
\hline Processing materials & 13.7 & 18.0 & 17.4 & 15.0 & 13.9 & 16.1 \\
\hline Processing imports & 13.5 & 27.2 & 30.8 & 32.1 & 35.7 & 40.3 \\
\hline Total & 27.2 & 45.1 & 48.2 & 47.1 & 49.5 & 56.4 \\
\hline \multicolumn{7}{|l|}{ Concessionary imports } \\
\hline Processing materials & 13.4 & 17.1 & 12.5 & 13.1 & 12.3 & 12.6 \\
\hline Processing imports & 11.5 & 22.1 & 22.5 & 28.0 & 31.9 & 32.5 \\
\hline Equipment for processing & 0.0 & 1.4 & 1.3 & 1.1 & 0.9 & 0.9 \\
\hline Foreign investor investment goods & 5.1 & 7.4 & 16.0 & 17.5 & 14.2 & 15.3 \\
\hline Processing for domestic sale ${ }^{\mathrm{d}}$ & & & 3.0 & 2.4 & 0.0 & 0.0 \\
\hline Total & 30.0 & 48.0 & 55.2 & 62.1 & 59.3 & 61.3 \\
\hline
\end{tabular}

Source: World Bank (1994, pp. 12, 59); China, GAC (1993, p. 157) and China Customs Statistics (1994:12, p. 12; 1995:12, p. 12)

a. Exports using concessionary imports are expressed as a percentage of total exports; concessionary imports, as a percentage of total imports.

b. See text for definitions

c. Numbers refer to first six months.

d. Not applicable before 1993.

reexport. The foreign business retains ownership and pays a processing fee to the Chinese enterprise. The factory in China plays a fairly passive role, taking orders and receiving materials from foreign trading companies. Indigenously owned factories, often township or village enterprises, account for the bulk of the export value (86 percent in 1995). In the second type of duty-free trade (jinliao jiagong)—here, called processing imports - the factory in China purchases the imported materials and organizes production and trade on its own. Foreign-invested firms account for the bulk of export value under this variant (74 percent in 1995). I refer to both variants together as export processing. ${ }^{32}$

Export processing has grown rapidly, along with the growth of foreign-invested enterprises. In 1995 export processing accounted for half of all exports and 90 percent of FIE exports. Processing imports, which is dominated by FIEs, is twice as important as processing materials, so FIEs accounted for 57 percent of all export processing. Table 4 shows the share of exports and imports in the main concessionary categories. Besides export processing, the duty-free import of investment goods for foreign investment projects has made up the largest portion of concessionary imports.

32. China, General Administration of Customs, China Customs Statistics (1995:12). 
Exemption from import duties on inputs provides a modest financial advantage to foreign-invested and other export-oriented producers. More important is the fact that export processing allows FIEs to sidestep entirely the complex and unwieldy apparatus of import controls, canalization, and regulatory monopolies that continues to restrict development of trade under the OT regime..$^{33}$ FIEs are permitted to engage directly in foreign trade. They are not required to go through state-run foreign trade corporations to import needed commodities, in contrast to virtually all domestic enterprises. Export processing is the fundamental institutional innovation that, along with the presence of FIEs, makes it possible to speak of a separate export promotion trade regime.

In addition to the ability to engage directly in foreign trade, a number of other concessionary provisions are applicable to export-oriented FIEs:

-Duty-free import of raw materials and components for export production.

-Duty-free import of investment goods. This used to be an acrossthe-board exemption for all FIEs. Automobiles were excluded after December 1994, and all tariff exemptions for investment goods are to be phased out by the end of 1997 .

- Concessionary income tax rates. The statutory corporate income tax rate in China is 33 percent (that is, 30 percent national plus 3 percent local income tax), but FIEs qualify for a variety of reduced rates on the basis of location (for example, a rate of 15 percent in the five SEZs and 15 to 18 percent in approved development zones in other regions; and a rate of 24 percent in large "open coastal zones" and the old urban districts in the fourteen "open coastal cities"). Moreover, firms designated as "export-oriented"' are eligible for an additional 50 percent reduction, irrespective of location.

- Significant tax holidays. Taxes are regularly remitted in the first two years of profit-making operation, and levied at 50 percent of the full rate in years three to five. Losses incurred during startup can be credited against profits to delay the onset of the first profit-making year.

- Competition between local jurisdictions to attract investment frequently leads to significant subsidies, either overt or implicit. Local

33. Canalization refers to restrictions on which particular FTCs can handle imports of a specific commodity. The central government might grant this right to a monopolist ("single desk") or to several firms. 
jurisdictions have been known to guarantee subsidized prices for land, utilities, and certain kinds of inputs, and they regularly collude with potential foreign investors to minimize central government taxation. ${ }^{34}$

Moreover, during the period of dual exchange rates, from 1986 through the end of 1993, FIEs had full access to the foreign exchange swap markets-where foreign exchange could be sold for yuan at market-clearing rates-while domestic enterprises were subject to variable restrictions and limits.

None of these concessions are unique. All are observed elsewhere in East Asia and, indeed, around the globe. The scale on which these provisions were introduced in China, however, is unusual. In most countries, such concessionary provisions are only applicable within a strictly policed export processing zone. In essence, China created a kind of gigantic export processing zone, defined not geographically, but by the juridical status of the enterprise involved. Although the SEZs attracted a lot of attention and were located near important economic centers in southern coastal China, they did not determine the extent of the export processing regime: export-oriented FIEs qualified, whether they were located in SEZs or not.

\section{The Ordinary Trade Regime}

Although the centralized monopoly has been dismantled, China's ordinary trade regime is still a heavily protected import substitution regime. Most domestic firms still operate in an environment significantly insulated from world prices. The most important feature is that virtually all ordinary trade must be channeled through state-owned companies (usually, foreign trade companies), which accounted for 92 percent of ordinary trade exports and 86 percent of ordinary trade imports in 1995. There are now more of these firms than in the past, some competition has been fostered between them, and their incentives have been changed. But there are still gatekeepers. This institutional continuity has shaped the development of the ordinary trade export and import regimes in different ways.

In the OT export regime, demonopolization has fostered significant entrepreneurship among FTCs. Exporting became lucrative with devaluation. In January 1994, when the exchange rate was unified, the gov-

34. Zweig (1995). 
ernment also instituted a VAT rebate program for all exports, paying the rebates directly to the FTCs. The combination of devaluation and VAT rebates caused a tremendous surge of exports: FTCs are unquestionably motivated by profit. ${ }^{35}$ The competition between FTCs has tended to drive the domestic price of exportables in the direction of world prices, sometimes creating upward pressure on the prices of raw materials, which the Chinese government considers undesirable. ${ }^{36}$

FTCs predominantly export on their own account, taking ownership of the goods produced by TVEs, SOEs, and private firms. The government has tried to persuade FTCs to make more use of the agency system - to market goods and charge the producers commissions, without taking ownership of the goods-but it has not been successful. The FTCs apparently find their gatekeeper positions profitable and prefer to maintain control over the flow of commodities. However, the institutional arrangements involved in exporting have changed significantly. Before reform, FTCs were primarily based in large cities, such as Beijing and Shanghai, and enjoyed monopoly rights that enabled them to procure and transship export goods from neighboring provinces. These were typically arms-length purchase agreements, based on longterm relationships and sanctioned by government plans. With reform, the older FTCs lost their monopoly rights when hundreds of competing FTCs were created, and many were no longer able to procure from their former suppliers, who had diverted output toward local FTCs. Thus Shanghai, for example, lost control of many exports to the neighboring provinces of Jiangsu and Zhejiang. But at the same time, FTCs gained the freedom to engage in more diverse business practices. By recontracting with domestic enterprises in a variety of ways, such as industrial subcontracting, enterprise groups, batch processing, they were able to retain some competitive edge. FTCs sought out the lowest-cost producers for labor-intensive goods: most often, TVEs. As a result, the share of exports produced by TVEs increased rapidly.

In the OT import regime, the progress of reform has been slower. Tariffs are high. A World Bank study finds that in 1992, China's tariffs

35. FTCs no longer receive overt subsidies for exports from the central government. However, they and the local governments that oversee them continue to be under pressure to meet informal export objectives. Local governments are often willing to subsidize loss-making exports, and FTCs sometimes cross-subsidize loss-making exports.

36. See Watson, Findlay, and Du (1989). 
were similar to those in other large and highly protectionist developing countries: the unweighted mean tariff was 43 percent and the tradeweighted mean tariff was 32 percent (the same as Brazil's). ${ }^{37}$ Moreover, China had sixty-nine different tariff rates, a greater number than any of the eight other developing countries analyzed. ${ }^{38}$ Tariffs were cut back slightly over the next four years. Then, on April 1, 1996, following a promise made at the Osaka summit of the Asia Pacific Economic Cooperation (APEC), unweighted average tariffs were further reduced from 35.9 percent to 23 percent. These are significant reductions, although China still has higher tariffs than all other APEC countries except Thailand.

Nontariff barriers are equally significant. Indeed, the same World Bank study points out that NTBs and tariffs "are used in a complementary fashion to achieve the government's objectives." 39 The World Bank finds that 51.4 percent of total imports in 1992 were subject to at least one of four different overlapping nontariff barriers: compulsory import planning, canalization, licensing, and a separate system of import controls for machinery. ${ }^{40}$ Import planning and machinery import controls have since been eliminated, and import licensing and canalization are now less extensive. Following commitments made to the United States, China has reduced the coverage of its import licensing program in annual increments. In mid-1996, twenty-eight categories of commodity were still subject to quota licensing, and another eight remained subject to compulsory canalization. ${ }^{41}$ Today, roughly 20 percent

37. World Bank (1994, p. 56).

38. Hungary had an even greater number of tariff rates (seventy-eight), but its unweighted mean tariff was only 15 percent.

39. World Bank (1994, p. 67). For example, many nonessential consumer goods are not subject to NTBs but do have prohibitively high tariffs. At the other extreme, a number of commodities are subject to low tariffs and restrictive NTBs. These are generally imports that were formerly planned and distributed by the government and are now regulated by less formal quantitative controls. For example, in 1992 grain, fertilizers, and steel had tariffs of less than 20 percent and together accounted for a significant share (14 percent) of total imports. All were subject to tight quantitative controls. Finally, in some important sectors, such as automobiles and industrial machinery, overlapping protection is provided by high tariffs as well as significant NTBs. (See also West, 1993.)

40. See, in particular, World Bank (1994, pp. 63-67, 82-84). Canalization was the most extensive NTB, covering 32 percent of imports.

41. "China Adjusts Catalogue of Import Licensing," China Economic News, August 19, 1996, pp. 1-16. Comparison with data from World Bank (1994, pp. 310-16) 
of China's imports are subject to formal quantitative controls, including most important raw materials and virtually all transport equipment. Since the initial system of NTBs had a great deal of redundancy, there is considerable scope for reducing apparent NTB coverage without surrendering effective control. There has clearly been a significant reduction in overall NTB coverage since 1992, but it is difficult to assess the extent of the change.

One source of ambiguity is the continuing role of the FTCs as gatekeepers. Before reform, the import of any good was the monopoly of a certain national FTC. Today, important elements of monopoly persist, due to the limitations of the liberalization process. In the first place, only FTCs, virtually all of which are state owned, are authorized to import goods for sale in the domestic market; the 3,400 production enterprises that have trading rights are only authorized to import for their own production needs..$^{42}$ In this sense, their position is similar to that of the FIEs described above, although they are subject to closer scrutiny. But import for sale in the domestic market requires the intermediation of a state-owned FTC. ${ }^{43}$ Moreover, FTCs are chartered to engage in business within a particular product range ("business scope"'), are often limited to a designated province, and are sometimes constrained to serve a specified category of customer. No FTC is free to choose what products it imports. A firm's business scope may be very narrow (especially if it includes a tightly controlled import) or relatively broad (in which case it typically will exclude all important

shows that the number of items subject to formal licensing under the harmonized customs system declined from 601 in 1992 to 348 in August 1996. The relaxation of controls has adhered closely to the schedule outlined by the Chinese Trade Ministry following the 1993 memorandum of understanding with U.S. trade negotiators; see West (1993, p. 24).

42. China has agreed to allow the establishment of foreign-invested trading companies. During 1996, three foreign companies (from Japan, Korea, and Germany) were granted permission to establish joint venture trading companies in the Pudong economic zone, in Shanghai. As of this writing, they have not started operation. ("China Opens a New Possibility of Joint Venture Trading Companies,' China Economic News, June 24, 1996, pp. 15-16.)

43. There is one small exception to this generalization: foreign-invested department stores (of which there are currently fourteen) are allowed to import directly up to 30 percent of turnover for sale in their own retail outlets, provided that they fund these imports with their own export earnings. ("China's Retail Trade Opens Wider to Foreign Investors," China Economic News, April 1, 1996, pp. 4-5.) 
categories of tightly controlled imports) ${ }^{44}$ Moreover, the bigger FTCs run by the central government account for a large share of trade, and many enjoy various kinds of formal and informal privileges. In 1993, the top five national FTCs imported 27 percent of total imports and a much larger share of OT imports. ${ }^{45}$ As a result, the ability to import and the degree of competition are substantially less than might be supposed from the total number of FTCs.

Another source of ambiguity is the fact that although the Chinese government has abolished a number of NTBs, it has subsequently introduced less formal procedures, such as "automatic registration," that have the potential to restrain trade in the same commodities. ${ }^{46}$ Such provisions should be considered in the context of the overall incentive environment in which FTCs operate. FTCs are granted their business scopes by government agencies that also have the authority to revoke the authorization. When demand for an imported commodity is high, or the commodity is deemed important, the authority to deal in that import is quite valuable. Therefore the limited number of FTCs that do have import rights have strong incentives to heed informal government guidance on the quantities imported. Moreover, given the potential geographic limitations on their operation, only a small number of FTCs may be authorized to handle a specific import in a particular region. ${ }^{47}$ Maintaining a comfortable monopolistic or oligopolistic position in the market is a strong incentive to accept administrative guidance. These

44. Dickson (1996, pp. 11-13); World Bank (1994, p. 115).

45. China, SSB (1995a, p. 231).

46. For example, Dickson (1996) describes the system of automatic registration that replaced import licensing for steel in 1994. Automatic registration appears to be less than automatic in most cases, and Dickson suggests that the system plausibly explains at least some of the 54 percent decline in steel imports between 1993 and 1995. Pei (1996) describes automatic registration for machinery commodities as a "transitional form" between NTBs and free trade.

47. Steel imports again provide a useful example. Fifty-five local and three national FTCs are authorized to import steel; in many cases, the local FTCs are former affiliates of the national FTCs. However, each local FTC is restricted to one of forty-two specific localities, and no locality has more than two authorized local FTCs. The national FTCs do not generally supply local users. As a result, the import of steel is a monopoly or duopoly, at least insofar as a local user is concerned. Steel is an important and highly controlled import. Most imports are not subject to such extreme control. (See Dickson, 1996.) 
institutional factors have significantly limited the impact of reform in the ordinary trade system, particularly as it pertains to imports. ${ }^{48}$

A final aspect of the import regime worth noting is that the actual tariff collection rate runs substantially lower than would be expected from the nominal tariff schedule. The actual tariff take has been a small and declining proportion of imports over the reform period: ${ }^{49}$

$\begin{array}{cc}\text { Year } & \text { Percent of total imports } \\ 1986 & 9.7 \\ 1989 & 8.4 \\ 1990 & 6.3 \\ 1991 & 5.6 \\ 1992 & 5.6 \\ 1993 & 5.9 \\ 1994 & 4.0\end{array}$

Comparison of these numbers with those in table 4 indicates that, under plausible assumptions about the distribution of the tariff burden, although the share of concessional imports is large, it is not large enough to account for the difference between nominal and actual tariff revenues. It appears that a substantial proportion of imports, especially capital goods, enter China without significant duties, even if not under the broad concessional programs. If Chinese imports are not primarily regulated by tariffs, the conclusion is unavoidable that they are regulated by a combination of tariffs, quotas, and administrative guidance exercised over state-owned trading companies.

48. Furthermore, in contrast to the export regime, most FTC imports are brought in on the agency system: FTCs procure imports for specific customers (who bear the related risk) and charge them a commission. On the positive side, the agency system promptly transmits world price relationships to the domestic economy (Lardy, 1992b). But if FTCs resist the agency system for exports, why do they not also do so for imports? Certainly, the market power of FTCs with import authority seems to surpass that of the exporters. Therefore FTCs that truly made use of their authority to import would be expected to import goods on their own account and reap above-normal profits. A plausible hypothesis about why FTCs do not behave in this way is that they understand that the permission to import is contingent on formal or informal authorization and that they must share the implicit rents with the designated purchasers, who are also clients of the governmental organizations that dispense permission to import.

49. World Bank (1994); Wang (1996, p. 23). 
Restrictions on import trade indirectly hamper the efforts of Chinese enterprises to export. Although thousands of domestic producers and traders have the authority to export directly, that authority does not confer an automatic access to imports: the ability to import is more restricted. ${ }^{50}$ This system severely limits a domestic firm's ability to respond quickly to changing market conditions or fashions and restricts its range of growth and cost-minimization strategies. A comparative study of the textile and clothing industry in Asian countries finds that China ranks lowest not only in prices, but also on all indexes of service and responsiveness (for example, fashion, customer service, orderdelivery lags, delay, and rejection rates), although in several instances its position is close to that of India and Pakistan. ${ }^{51} \mathrm{~A}$ system that insulates producers from final consumers is at least partly responsible for this poor service record. Finally, trading privileges are typically granted only to the largest production enterprises, which already have substantial exports, so it is particularly difficult for new and smaller firms to enter export markets. The existing trade system, although reformed, still holds back potential exporters.

\section{Outcomes of Trade Reform}

The creation of a dualistic trading regime is one element of a program of trade reform that has reshaped every aspect of China's foreign trade. The most obvious result of the reform program is the startling growth in Chinese trade documented in the opening paragraphs of this paper. Along with quantitative growth has come dramatic structural change. Most important have been the dramatic shift to the production of laborintensive commodities and a correspondingly large decline in the production of goods based on natural resources. As late as 1985, petroleum was China's largest export, accounting for 20 percent of export earnings. By 1995, however, all of China's top export commodities were labor-intensive manufactured goods. According to the International Economic Databank maintained at the Australian National University, between 1984 and 1994, the share of labor-intensive products in China's

50. Successful exporters can generally count on a sympathetic hearing when they apply for permission to import important raw materials and inputs, but their ability to respond quickly and flexibly to import opportunities is quite limited.

51. Crowley, Findlay, and Gibbs (1991). 
exports increased from 37 percent to 54 percent, while the combined share of agricultural and minerals-intensive products declined from 49 percent to 15 percent. In addition, over the same period, capitalintensive exports increased from 14 percent to 31 percent of total exports, suggesting to some analysts that not only has there been an important transition away from resource-intensive and toward laborintensive exports, but also, "the transition out of labor intensive products has already begun." ${ }_{52}$ Breakdowns of export composition by trade regime are not available, but it appears that there was a significant shift toward labor-intensive manufactures in both the export promotion and the ordinary trade regimes.

While the composition of China's exports has shifted to much better reflect China's abundant labor endowment, imports continue to be concentrated in capital- and technology-intensive products. It is the much larger volume of imports, rather than radical changes in their composition, that has increased China's gains from trade. Capital-intensive products continue to account for about two-thirds of imports. On closer inspection, many of these commodities serve essentially as substitutes for land, stretching China's limited land endowment: major examples include fertilizers, food grains, synthetic fiber materials, and iron ore. China's trade broadly reflects its comparative advantage and is of enormous benefit to the domestic economy.

Although liberalization has much improved the overall incentives to engage in trade, the dualistic nature of the new regime has significant diversionary effects on trade. The EP regime is much more open to trade than the OT regime and has a number of concessionary attributes: the private returns to any given trading activity are typically higher if that activity can be carried out under the EP regime. ${ }^{53}$ As a result, trade

52. Findlay and Watson (1996, p. 6). A number of studies have described the shift to labor-intensive manufactures in Chinese exports. The World Bank (1994, p. 9), using a different classification system, based on U.S. factor proportions, finds that laborintensive manufactures grew from 39 percent to 74 percent of total exports between 1980 and 1990, with unskilled labor-intensive goods accounting for 29 percent and 51 percent of total exports, respectively. Lardy (1992a) analyzes Chinese exports on the basis of Chinese factor proportions as reported in the 1985 industrial census and finds a marked shift toward more labor-intensive exports since 1985.

53. At the margin, there must have been numerous cases of pure Vinerian trade diversion-suppliers with higher real resource costs displace potentially lower cost suppliers, due to distortions in the incentive system. However, it is unlikely that those static inefficiencies were significant in comparison with the dynamic consequences of 
growth has inevitably been diverted and concentrated in geographical areas and ownership forms where the EP regime is more developed.

The diversionary effects of China's dualistic trade strategy are particularly apparent in the changing regional pattern of exports. The EP trade regime was pioneered in the southeastern coastal province of Guangdong, and its privileges were early extended to neighboring Fujian province, contributing to the rise of those regions as the center of China's export economy. Even today, the EP regime is more fully developed and more free in Guangdong and Fujian than in the rest of China. In part, this is due to the location of special economic zones in these provinces, in part, to their greater provincial autonomy, and in part, to the cumulative effect of many traders and investors. ${ }^{54}$ Guangdong was moderately important in Chinese foreign trade in 1978, accounting for 14 percent of total exports; by 1994, that figure had grown to a remarkable 44 percent. For Fujian, the comparable figures are 2 percent and 5 percent. In 1994, the two provinces-accounting for 8 percent of China's population and 12.7 percent of GDP-accounted for almost half of China's exports, and an even larger share of export growth. Table 5 shows the breakdown of export growth between 1984 and 1993 , by province. ${ }^{55}$ Guangdong and Fujian accounted for a re-

the choice between alternative liberalization strategies. The trade diversion argument is introduced not to inveigh against inefficiencies, but to explain some of the main patterns of Chinese trade growth.

54. Smuggling makes the de facto trade regime in these provinces even more free. Both have long and rugged coastlines that facilitate the movement of substantial quantities of contraband. The fact that the EP regime is not circumscribed by geographical boundaries means that significant leakage is inevitable.

55. The numbers presented in table 5 have some shortcomings, primarily because they classify exports by location of exporter, rather than by location of producer. In $1984,8.7$ percent of exports (6.1 percent in 1993) were exported by central government trading companies that are not assigned a provincial location in the data sources. In addition, the 1984 data are from the Chinese Ministry of Foreign Trade, which evaluates processing materials trade (lailiao jiagong) only by net processing fees earned. The first problem is significant for export statistics for cities such as Shanghai and Tianjin, which have experienced substantial shifts in the location of primary exporters, but is not of much consequence for Guangdong or Fujian, since these provinces were never major secondary exporters. The discrepancy associated with the treatment of processing materials trade in different sources is probably not large, because the volume of processing trade was quite small in 1984. The Ministry of Foreign Trade's figure for total exports in that year is not quite 7 percent less than that given in the official customs statistics, and some of this discrepancy is due to other exports that do not earn foreign exchange 
Table 5. Export Growth, by Province, 1984-93

Units as indicated

\begin{tabular}{|c|c|c|c|}
\hline \multirow[b]{2}{*}{ Province } & \multicolumn{3}{|c|}{ Export growth } \\
\hline & Total $^{\mathrm{a}}$ & $\begin{array}{l}\text { Percent by foreign- } \\
\text { invested enterprises }^{\mathrm{b}}\end{array}$ & $\begin{array}{c}\text { Percent of national } \\
\text { export growth }\end{array}$ \\
\hline Guangdong & $34,909.2$ & 41.2 & 54.6 \\
\hline Fujian & $4,735.0$ & 52.6 & 7.4 \\
\hline Zhejiang & $3,586.0$ & 27.3 & 5.6 \\
\hline Jiangsu & $3,164.3$ & 47.5 & 4.9 \\
\hline Shanghai & $2,978.8$ & 59.8 & 4.7 \\
\hline Shandong & $1,913.2$ & 46.5 & 3.0 \\
\hline Heilongjiang & $1,347.4$ & 6.7 & 2.1 \\
\hline Jilin & 955.4 & 7.0 & 1.5 \\
\hline Sichuan & 939.5 & 8.9 & 1.5 \\
\hline Hebei & 918.5 & 18.0 & 1.4 \\
\hline Hainan & 878.7 & 8.1 & 1.4 \\
\hline Tianjin & 823.7 & 73.6 & 1.3 \\
\hline Hubei & 768.9 & 17.4 & 1.2 \\
\hline Hunan & 720.6 & 5.9 & 1.1 \\
\hline Yunnan & 685.2 & 3.7 & 1.1 \\
\hline Shaanxi & 638.3 & 4.7 & 1.0 \\
\hline Guangxi & 571.8 & 18.7 & 0.9 \\
\hline Anhui & 540.9 & 11.6 & 0.8 \\
\hline Beijing & 514.9 & 65.8 & 0.8 \\
\hline Henan & 408.8 & 16.8 & 0.6 \\
\hline Inner Mongolia & 405.9 & 6.6 & 0.6 \\
\hline Jiangxi & 380.3 & 10.8 & 0.6 \\
\hline Shanxi & 240.6 & 20.4 & 0.4 \\
\hline Xinjiang & 215.6 & 11.5 & 0.3 \\
\hline Liaoning & 177.4 & 655.7 & 0.3 \\
\hline Gansu & 173.4 & 8.6 & 0.3 \\
\hline Guizhou & 162.1 & 7.4 & 0.3 \\
\hline Tibet & 103.9 & 1.3 & 0.2 \\
\hline Qinghai & 76.3 & 0.0 & 0.1 \\
\hline Ningxia & 31.9 & 9.4 & 0.0 \\
\hline
\end{tabular}

Source: Author's calculations. Data for 1984 are from China, SSB (1990a, 1990b); and for 1993, from China, GAC, China Customs Statistics (1993:12, pp. 12-15).

a. Millions of dollars.

b. Increase in exports by foreign-invested enterprises as a share of total increase in exports from a given province. 
markable 62 percent of total export growth over the period. Exports from Guangdong grew at 35 percent annually, and those from Fujian grew at 32 percent annually. By contrast, exports from the rest of China (including those by central government trading companies) grew by 8.7 percent per year. ${ }^{56}$

The geographic concentration of trade growth has given rise to enormous differences in the importance of trade in individual provincial economies. Table 6 shows that in 1994, Guangdong's ratio of exports to provincial product was 106 percent, while the average ratio for the rest of the country was 14 percent. There is a tendency to think that all of the rapidly growing coastal provinces are open to trade, but in fact there are huge differences in the degrees of their export dependency. Other coastal provinces-including Zhejiang, Jiangsu, and Shandong-have grown more rapidly than the national average, despite having much lower foreign trade ratios than Guangdong, as well as much lower participation by foreign capital. Particularly striking is the province of Jiangsu, which has been growing extremely rapidly in recent years and yet had an export-to-provincial product ratio of only 14.5 percent in 1994. Indeed, one of the most distinctive characteristics of economic growth in China has been its broad geographical spread. Despite the immense flood of foreign investment into Guangdong and Fujian, the GDP growth rates of these provinces have been only slightly above the national average. Thus, while China has experienced rapid growth in both exports and GDP, the provincial evidence is not clear on the causal relationship between the two.$^{57}$ Foreign trade and investment have been highly geographically concentrated, but the acceleration of economic growth has been very broadly based.

and are not counted in the Ministry of Foreign Trade's data. An example is Chinese foreign aid, which has been significant in some years.

56. It is equally striking to look at regional exports as a share of world trade. In 1984 Guangdong and Fujian accounted for 0.15 percent of world exports; by 1993, 1.19 percent. The rest of China, by contrast, accounted for 1.22 percent of world exports in 1984 and 1.37 percent in 1993. Although exports from the rest of China grew more rapidly than world exports overall, the difference between China and the rest of the world was not dramatic.

57. In this sense, China may lend support to the strand of development literature that questions the causal link between export growth and GDP growth; see, for example, Jung and Marshall (1985) and the subsequent literature. At the city level, however, Wei (1995) does find evidence of a significant link between foreign direct investment and GDP growth. 
Table 6. Exports by Domestic and Foreign-Invested Firms, by Province, 1994

Percent of provincial GDPa

\begin{tabular}{|c|c|c|c|}
\hline \multirow[b]{2}{*}{ Province } & \multicolumn{3}{|c|}{ Exports } \\
\hline & $\begin{array}{l}\text { Domestic } \\
\text { firms }\end{array}$ & $\begin{array}{l}\text { Foreign-invested } \\
\text { firms }\end{array}$ & Total \\
\hline$\overline{\text { Guangdong }}$ & 66.5 & 39.5 & $\overline{106.0}$ \\
\hline Shanghai & 31.1 & 11.4 & 42.5 \\
\hline Tianjin & 23.4 & 11.8 & 35.2 \\
\hline Fujian & 16.1 & 14.4 & 30.4 \\
\hline Beijing & 26.1 & 3.8 & 30.0 \\
\hline Zhejiang & 17.2 & 3.3 & 20.5 \\
\hline Liaoning & 11.6 & 5.3 & 16.8 \\
\hline Heilongjiang & 14.5 & 0.6 & 15.1 \\
\hline Jiangsu & 10.2 & 4.3 & 14.5 \\
\hline Jilin & 13.2 & 1.2 & 14.4 \\
\hline Shandong & 10.7 & 3.5 & 14.2 \\
\hline Hainan & 9.8 & 1.4 & 11.1 \\
\hline Shanxi & 10.0 & 0.8 & 10.8 \\
\hline Guangxi & 8.1 & 1.0 & 9.1 \\
\hline Shensi & 7.8 & 0.4 & 8.2 \\
\hline Yunnan & 7.4 & 0.2 & 7.6 \\
\hline Hebei & 6.4 & 1.1 & 7.5 \\
\hline Qinghai & 6.8 & 0.2 & 7.0 \\
\hline Hubei & 6.1 & 0.7 & 6.8 \\
\hline Ningxia & 6.0 & 0.4 & 6.4 \\
\hline Hunan & 5.9 & 0.3 & 6.2 \\
\hline Inner Mongolia & 5.4 & 0.5 & 6.0 \\
\hline Gansu & 5.5 & 0.3 & 5.8 \\
\hline Xinjiang & 5.3 & 0.4 & 5.7 \\
\hline Anhui & 5.1 & 0.4 & 5.5 \\
\hline Jiangxi & 5.0 & 0.4 & 5.3 \\
\hline Sichuan & 4.3 & 0.3 & 4.6 \\
\hline Guizhou & 4.0 & 0.3 & 4.4 \\
\hline Henan & 3.8 & 0.4 & 4.2 \\
\hline Tibet & 3.3 & 0.2 & 3.5 \\
\hline All provinces & 16.0 & 6.4 & 22.4 \\
\hline Excluding Guangdong & 10.8 & 3.0 & 13.8 \\
\hline
\end{tabular}

Source: Author's calculations based on data from China, SSB (1995b, pp. 33, 552-53).

a. GDP is converted into dollars at the average 1994 exchange rate (8.62 yuan to the dollar). 
The rapid expansion of labor-intensive manufacturing in Guangdong might have run into labor constraints, even given the 35 million workers in the province. In fact, interprovincial migration has ensured an abundant labor supply. By the end of 1995, there were 6.5 million workers from outside the province in Guangdong, about 3 million of whom were in manufacturing establishments, many of them FIEs. ${ }^{58}$ In this case, China's huge population has facilitated the rapid growth of an export complex. Guangdong has been able to continue to expand laborintensive manufacturing at extremely high rates, in part, because of the nearly infinitely elastic supply of labor in China as a whole.

Diverse regional experience is not explicable solely in terms of trading regimes. It is not an accident that of the two most successful exporting provinces, Guangdong is adjacent to the vibrant capitalist metropolis of Hong Kong, and Fujian is across the water from Taiwan, with which it shares a regional dialect. The rapid growth of laborintensive manufactured exports in China is the result of a large-scale transfer of production capacity from Hong Kong and Taiwan to the mainland, in order to obtain lower production costs. In this light, the export promotion regime can be seen as China's response to a particular opportunity arising from the needs of earlier industrializers to restructure their own manufacturing and trading regimes. This restructuring, already overdue, was forced by the currency realignments of the $1980 \mathrm{~s}$ (see figure 5). Through the liberal EP regime, China was able to accommodate the interests of existing exporters in Hong Kong and Taiwan and become the preferred relocation site for labor-intensive exporters.

The resulting production displacement is evident in the changing shares of various Asian producers in the U.S. market. For a long list of commodities-including athletic shoes, other sporting goods, toys, and household electronics-a declining market share for Taiwan or Hong Kong is matched by an increasing market share for China. Marcus Noland performs a constant market share analysis of exports from China to the United States and shows that China's increased market share in the United States comes almost entirely at the expense of Taiwan and Hong Kong. ${ }^{59}$ "Expense"' is perhaps misleading here, because clearly the shift in production does not harm Taiwanese and Hong Kong firms.

58. Zhang (1996).

59. Noland (1996). 
To the contrary, they retain control of production and of the associated export networks and benefit from access to cheaper Chinese labor.

Thus the success of the EP policy is, in large part, a function of its ability to facilitate the transfer of production from other countries to China. In turn, much of Hong Kong investment in China represents the ordinary process of growth of a metropolitan economic region, expanding outward in roughly concentric circles. As Hong Kong has grown, its central business district has become increasingly expensive and dominated by finance and business services, which produce high levels of output per unit of space. This has pushed space-intensive activitiesincluding manufacturing, housing, and recreation-out to the urban periphery. Because of an accident of history, in Hong Kong's case, such relocation moves goods across an international boundary: it represents foreign investment and creates foreign trade. ${ }^{60}$ In this sense, the liberal export regime that China created in the 1980s was simply a way to provide space for the expansion of the Hong Kong economy (and, ultimately, that of Taiwan). Chinese policymakers recognized and successfully exploited a dramatic opportunity.

The powerful incentives created by the EP regime also divert trade within China's dualistic trade system. Consider the predicament of a Chinese SOE that sees an export opportunity. Even if it is able to obtain direct trading rights within the OT regime, it still faces significant constraints on its access to imports, freedom of management, and access to financing. The obvious way to escape these constraints, and also to escape the punitive tax rates imposed on SOEs, is to form a joint venture with a foreign (Hong Kong) partner. And if this joint venture can be located in a region, such as a special economic zone, where tax rates are lower and other regulations are more lenient, the benefits will be even greater. Many manufacturing firms from provinces with low trade ratios (such as Jiangsu) have set up joint venture subsidiaries in the Shenzhen SEZ, next to Hong Kong. Even if the initiative for, and managerial control of, such an undertaking comes from the SOE, its exports will show up in the statistics as those of a Guangdong-based foreign-invested enterprise. At its extreme, this type of trade diversion

60. An identical process can be observed in the other Asian city-state, Singapore. It has become fashionable to refer to the resulting flows of goods across borders as a growth triangle, but it is hard to see how that adds to an understanding of metropolitan growth. 
occurs when a Chinese SOE sets up a subsidiary in Hong Kong to serve as a "foreign investor" in China. Chinese corporations of this kind represent a significant share of the Hong Kong parents of Chinese FIEs producing exports. ${ }^{61}$ The EP regime gives domestic firms powerful incentives to change ownership forms and relocate their production and trading activities. Thus the differences between the incentive systems under the EP and OT regimes tend to divert trade away from SOEs and toward foreign-invested joint ventures and also toward the provinces of Guangdong and Fujian.

\section{Recent Developments}

It should be apparent that the configuration of Chinese reform policies, both domestic and foreign, has created powerful incentives for the agents who determine the development of foreign trade and investment. In the past couple of years, those forces have created a new set of challenges with respect to foreign trade liberalization. In essence, China chose to liberalize access for foreign investors to the domestic market before substantively liberalizing the import regime. Given past protection of the domestic market and the relative success of the reforms, it was inevitable that this policy choice led to inflows of direct investment and thus to currency appreciation. In addition, earlier foreign trade liberalization had created an extensive web of privileges from which foreign investors could benefit. In this way, China's policymakers created an incentive system that strongly favors incoming investment directed at the domestic market and discourages imports and, hence, trade in general. These developments run counter to the repeatedly reaffirmed long-run objective of moving toward a more liberal foreign trade re-

61. The actual share is not known, and estimates vary. The only precise figure of which I am aware relates to Shanghai, where 15 percent of realized foreign investment over the period 1980-92 came from Chinese subsidiaries in Hong Kong. This was just under a third of total Hong Kong investment in Shanghai. (Tian, 1994, pp. 335-36.) It is likely that Chinese firms represent a smaller proportion of total Hong Kong investment in Shanghai, since they are likely to be less prominent in labor-intensive manufacturing in Guangdong, which accounts for the bulk of Hong Kong investment. Lardy (1995) reports estimates that up to 25 percent of total Hong Kong investment comes from Chinese firms. It should be noted, however, that some Chinese firms have been in Hong Kong since 1949 and have strong economic presences there: not all such investment is covert round-tripping. 
gime. Recent policy developments can be seen as attempts to navigate these conflicting currents.

The economic situation that exists today was made possible by the successful devaluation and unification of currency rates at the beginning of 1994, an important milestone in Chinese economic policy. The real devaluation was significant, but even more so were the unification of rates and the adoption of a managed float. Previous devaluations had never led to an equilibrium market exchange rate: excess demand for foreign exchange persisted at each new official rate. Even on this occasion, policymakers had no firm expectations of what the equilibrium rate would be. They simply chose an arbitrary rate close to the former swap market rate and hoped that subsequent fluctuations would not be too large. In fact, as figure 6 shows, the value of the yuan began to drift upward almost immediately. With the current account near balance and large inflows of foreign investment, the supply of dollars was abundant.

The devaluation had immediate, but assymetrical, effects on trade flows in the two trade regimes (see figure 7). Traders in the OT regime, who had previously converted at the official rate, experienced a substantial devaluation, whereas EP traders, who previously had access to foreign exchange at the swap market rate, experienced only minor changes (figure 6). Moreover, although the general rebate of VAT to exporters went into effect at the beginning of 1994, the FIEs (the primary EP exporters) were not eligible for VAT rebates during 1994 and 1995 , since they already enjoyed a number of other tax concessions. As a result, in a reverse of earlier patterns, OT exports grew more rapidly than EP exports from May 1994 until May 1995. In fact, EP exports did not deviate significantly from their long-run growth trend, posting a 37 percent increase during 1994, but OT exports surged by 42 percent for the year, and OT imports declined by 6.6 percent. The 1994 devaluation created an apparently stable exchange rate with an appreciating trend. ${ }^{62}$

In an effort to slow appreciation, the central bank began to accumulate foreign exchange reserves. These grew dramatically from $\$ 21.2$ billion at the end of 1993 to $\$ 73.6$ billion at the end of $1995 .{ }^{63}$ Moreover, the central bank largely sterilized the impact of the capital

62. This trend was conditional on maintaining existing NTBs.

63. China, SSB (1995b, p. 574; 1996b, p. 44). 
Figure 6. Real Exchange Rate of the Yuan against the Dollar, 1983-96

Index, $1987=100^{\mathrm{b}}$

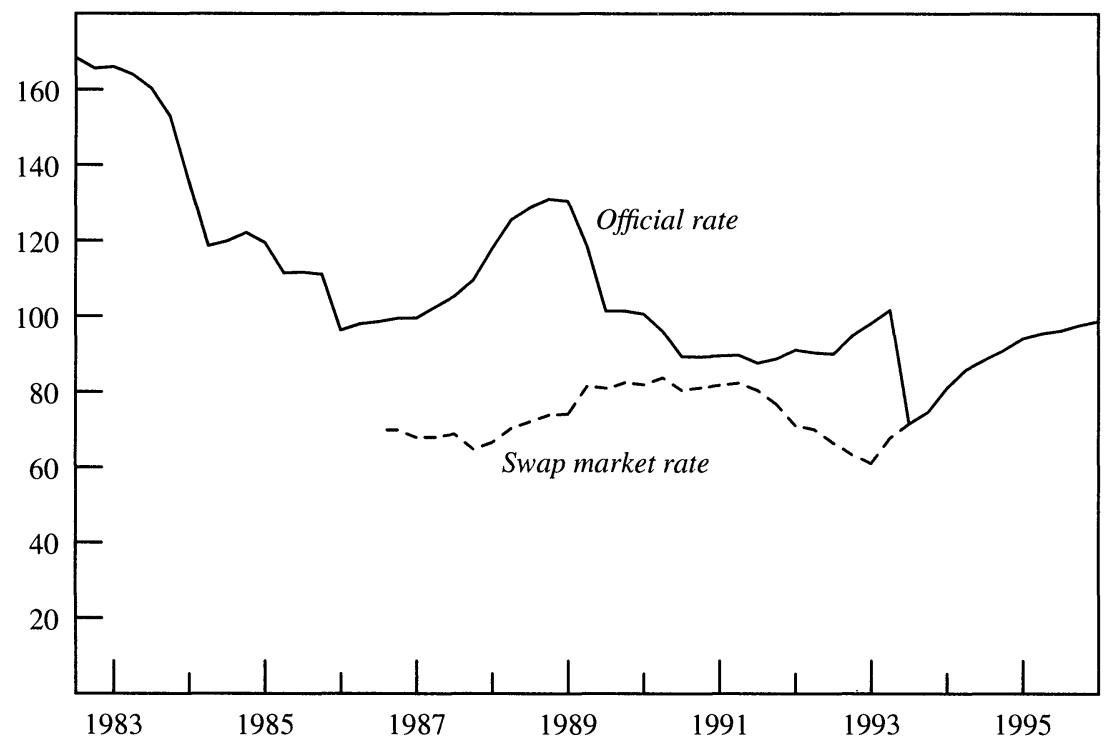

Source: Author's calculations based on data from China, Statistical Information and Consultancy Centre (various years); China Finance Association (1994, pp. 449-53) and China finance (various issues); World Bank (1994, p. 187); International Monetary Fund, International Financial Statistics (various years). U.S. prices used to calculate the real exchange rate are measured as the GDP deflator; Chinese prices, as the Chinese consumer price index (urban and rural aggregate).

a. Data are quarterly. Tic marks correspond to third quarter observations. Third quarter datum for 1996 is preliminary.

b. Based on price of yuan in dollars, so that an increase represents a yuan appreciation. 100 represents the average of four quarterly values for 1987

inflow on the money supply by reducing central bank lending growth almost to zero and drawing in reserves from commercial banks. Despite the accumulation of reserves, the nominal exchange rate drifted upward, appreciating about 8 percent between January 1994 and early 1996. This set of apparently favorable conditions soon began to create unforeseen problems. The government had not expected the flood of exports that resulted from the devaluations and the new VAT rebate program. In 1994 it paid back 44.5 billion yuan under the rebate program, but was still left with 25 billion in arrears at year's end. The following year, 55 billion yuan were rebated, but arrears reached a peak of 60 billion. Already facing severe budgetary difficulties, the govern- 
Figure 7. Annual Export Growth by Type of Firm Ownership and Trade Regime, March 1994 to July 1995

Percent change from previous year



Source: China, GAC (various years).

a. Annual percentage change of three-month moving average.

ment ran into a cash flow constraint. ${ }^{64}$ It responded by chopping back the VAT rebate program. Initially, exporters had been rebated the full amount of the VAT, set at 17 percent for most manufactured goods. In mid-1995 this rebate was reduced to 11 percentage points and at the beginning of 1996, to 9 percentage points. Since the reductions were announced in advance, in the short run they caused a rush of exports to beat the deadline and qualify for the full rebate. Combined with the delayed effects of devaluation, this accounts for the phenomenal surge of exports in the first half of 1995, shown in figure 7.

64. Wang (1996, p. 22); “Exchange Rate Changes and Macroeconomic Adjustment," China Economic News, July 29, 1996, p. 15. These problems with the rebate program were exacerbated by conflicts of interest and by fraud. All rebates were the resonsibility of the central government, but initial collection of the VAT sometimes required local government cooperation. In some localities, the government rebated more VAT than had been collected. 
However, substantial domestic inflation was eating away at the achievements of the nominal devaluation. Fueled by monetary excesses during 1992-93, inflation actually accelerated in 1994. Farm prices surged in mid-1994, pushing up the overall consumer price index (CPI). Because it would have been too politically sensitive to respond by liberalizing imports, the government left import barriers on farm products virtually unchanged and relied on a tight credit policy to tame inflation. The tight money policy gradually achieved some success: as of June 1996, CPI growth on a year-to-year basis was at 8.6 percent, down from its peak value of 27.7 percent in October 1994. Nevertheless, the cumulative price level increase between January 1994 and the beginning of 1996 exceeded 35 percent. Between early 1994 and mid1996, the nominal exchange rate appreciated by 8 percent, while the inflation differential between China and the United States reached 30 percent, yielding a real appreciation of 38 percent in the Chinese currency between the first quarter of 1994 and the third quarter of 1996. In 1996 this appreciation, combined with the reductions in the VAT rebate, had a significant effect on Chinese trade performance.

During the first half of 1996, overall Chinese exports were down by 8.2 percent from the first half of 1995. After many years of doubledigit export growth, a decline of this magnitude is significant. The differential changes in exports by trade regime and ownership are even more so. As figure 7 shows, OT exports are down by 29 percent in the first half of 1996, while EP exports are up by 15 percent and FIE exports are up by 38 percent (close to their long-run growth trend). It is striking that FIEs have been so little affected by the appreciation - this probably reflects the relatively small proportion of export value that is actually created within China. Since most raw materials and components are imported, within-China costs represent a relatively small proportion of total commodity value and are also small relative to setup costs. By contrast, the drop in OT exports is large and should alarm Chinese policymakers. Similarly, exports by indigenous Chinese firms (that is, total exports less those by FIEs) declined by 25 percent in the first half of 1996. Even though a number of one-time factors have made this decline particularly large, the fundamental factors retarding export growth are likely to persist. ${ }^{65}$ Moreover, Chinese policymakers do not 
seem to have anticipated the decline: in early 1996 , they were projecting export growth of 18 percent for the year. ${ }^{66}$

Chinese leaders have repeatedly reaffirmed that the long-range objectives of trade reform are a more open trade regime and membership in the World Trade Organization (WTO). A prerequisite of the latter is "national treatment" for FIEs; that is, that they not be subject to legal requirements that do not also apply to domestic firms. To this end, the Chinese have begun to take a number of steps to reduce, and ultimately eliminate, the differences between the present export promotion and ordinary trade regimes. ${ }^{67}$ Some of these changes have been mentioned above: tax breaks on investment goods for FIEs are being phased out; other aspects of tax treatment are becoming more unified; and there are plans to reduce the scope of tariff exemptions for all entities, foreign and domestic. Ironically, one of the immediate effects of this last policy will be an increase in the taxes levied on the foreign trade sector. Even as the average nominal tariff comes down, the actual tax take as a share of imports will probably increase. On balance, this is good, since it will tend to substitute regulation by tariffs for regulation by NTBs.

If implemented, these reforms will tend to unify the trading regimes, and the resulting system will be more open than the present dual regime. However, in the short run, the unification process may well mean that FIEs have less autonomy and pay higher taxes than they do today. They may also encounter more paperwork. For example, this year, a new system is being instituted to track production inputs that are imported

as follows. First, during early 1995, exporters rushed to get commodities out of China in order to qualify for full VAT rebates. That not only pushed up the base period for comparison, but may also have resulted in stockpiles of Chinese goods in Hong Kong that have to be worked off. Second, at the beginning of 1996, many FTCs were still owed billions of yuan in VAT rebates by the Chinese government. Without these funds, some FTCs have not been able to procure export commodities, because credit is still tight. The Chinese government has been working down the backlog of VAT rebate arrears since the spring of 1996. Third, during 1994 and 1995, some FIEs were selling export commodities to FTCs in order to share the benefits of the VAT rebate program, from which FIEs were temporarily excluded. Since 1996, FIEs engaging in ordinary trade have also been eligible for VAT rebates, and so the proportion of FIEs engaging in such trade on their own account has increased. This would mean a slight (at most, 3 percentage point) reduction in the FIE export growth rate and corresponding adjustments to the rate of decline of non-FIE exports. (China Economic News, May 6, 1996, pp. 12; August 5, 1996, p. 19.)

66. China Economic News, January 15, 1996, p. 2.

67. Zhu (1996). 
duty free and ensure that they are, in fact, used in the production of commodities for export. Since the diversion of duty-free imports to the domestic market has been widespread, some such measure is probably necessary, but it will certainly create a less freewheeling environment for the FIEs. The Chinese government has committed to national treatment for FIEs by the year 2000, although this schedule may be too optimistic. The first steps are being taken this year in the Shenzhen SEZ ${ }^{68}$ It is important to note that further liberalization will not entail convergence to the extremely open regime under which FIEs in southern China currently operate. Instead, trade in both regimes will be subjected to a uniform set of rules that will make the domestic economy overall significantly more open to the world economy, but will impose more tariffs and regulations on certain traders than at present.

\section{Trade Prospects}

China's growth has gained enormous momentum. However, it is likely that GDP growth will gradually slow down. It appears that the existing statistical system slightly overstates current growth rates. Rather than the official growth rate of 10.2 percent per year, growth over the past decade has probably been closer to, perhaps even slightly less than, 9 percent. As discussed above, changes in the labor force may reduce GDP growth rates by more than 2 percentage points. Thus GDP growth rates are likely to decline gradually to about 6 percent per year by $2015 .{ }^{69}$ In addition, there is substantial reason to believe that export growth will slow in relation to GDP growth. This section discusses five factors that will determine the trajectory of China's trade policy in the future: exchange rate management; tensions over the pace of import liberalization; regional development; technological development; and competition for export markets, particularly with members

68. China Economic News, April 1, 1996, pp. 1-2. One of the first steps taken in Shenzhen was to eliminate the practice of charging nationals and foreigners different prices for transportation, which has irritated foreigners in China for many years. Other, more substantive, measures are to be phased in over the next few years.

69. Similar slowdowns in GDP growth are observed in most middle-income economies, including Taiwan and Korea. China's case is different because the slowdown will probably come at an earlier stage of economic development, due to the earlier incidence of structural demographic change. 
of the Association of Southeast Asian Nations (ASEAN). On balance, examination of these factors suggests that the liberalization and unification of China's trade policy will continue, but in a way that will slow the country's heretofore rapid integration into the world economy.

\section{Exchange Rate Management}

China's experience since 1994 has many features in common with those of other successful developing countries. Granting outsiders access to the new opportunities created by liberalization causes an inflow of capital. Even without a significant inflow of portfolio capital, the influx of foreign direct investment in China has been sufficient to create a substantial real appreciation. Capital inflows create upward pressure on the currency, undermining the competitive position of exporters. In this sense, size of the economy or, rather, its projected size, has a negative effect on export competitiveness that is somewhat similar to the effect of a substantial natural resource endowment.

Moreover, capital inflows are disproportionately attracted into the most protected sectors of an economy, thus creating significant misallocation of resources. Chinese government policy aggravates this misallocation by targeting sectors in which China is unlikely to have a comparative advantage: passenger automobiles are a good example. In this respect, China is replicating some of the worst features of the import substitution model, as practiced by Brazil and Mexico until the 1980s. Yet the challenges to exchange rate policy are not solely due to the persistence of import barriers, nor is it likely that radical import liberalization would reduce inflows of foreign direct investment. On the contrary, opportunities within China are sufficiently abundant, and tax rates sufficiently low, that comprehensive liberalization would probably increase capital inflows, albeit with a different sectoral composition. In this sense, short-run changes in currency values reflect longrun fundamentals: China's domestic market is large compared with its potential export markets.

At present, the Chinese market seems to be attractive enough to ensure high inflows of foreign direct investment for the foreseeable future. During the first four months of 1996, despite currency appreciation and general uncertainty stemming from the considerable political tensions between China and Taiwan, realized inflows of foreign direct 
investment were up by 21 percent from the first four months of the previous year, according to official Chinese data. Tellingly, Taiwan data also show that approvals of new investment from Taiwan to the mainland rebounded strongly in June 1996, just months after China had lobbed missiles around Taiwan's busiest ports. ${ }^{70}$ This indicates that the attraction of investment in China goes beyond the country's potential as an export platform and is reasonably robust in the presence of political uncertainty. Inflows of foreign direct investment may not grow significantly, but, barring major domestic disruption, they are unlikely to drop dramatically. They are already so large that merely maintaining current levels will suffice to sustain upward pressure on the currency.

Thus far, EP exporters (primarily FIEs) seem to have been immune from the effects of currency appreciation, due to their low share of incountry costs. To a certain extent, increased FIE exports will continue to make up for reduced exports by domestic firms. Nevertheless, cost increases certainly have cut into the margins of FIEs, and impending changes in the legal system will reduce other concessionary benefits. The reaction of export-oriented foreign investors will probably exhibit substantial lag effects: overseas projects take time to plan, construct, and bring up to speed, and investment in China now has substantial momentum. But over time, the cost competitiveness of labor-intensive manufacturing in China is likely to decline. ${ }^{71}$ The result will be a reduction in export-oriented foreign direct investment, which may be offset by increases in foreign direct investment in the domestic market. The response of domestic exporters to currency appreciation, by contrast, has been rapid and may be difficult to reverse. Sharp reductions in exports by firms that have already established export contacts, invested in knowledge about export markets and intermediaries, and paid other startup costs, should be viewed quite seriously.

70. China Statistics Information News, China's Latest Economic Statistics, June 1996, p. 52; Deborah Shen, "Inward Investment Dips in First Half of the Year," Free China Journal, July 19, 1996, p. 8.

71. A large share of China's exports is procured by foreign importers, rather than being marketed by domestic exporters. Such "buyer-driven commodity chains" are often formed by retailers or designers from developed countries in alliance with supply companies based in Hong Kong and Taiwan, many of which now operate or subcontract production facilities on the Chinese mainland. The production of Nike shoes is a good example of this process. These chains are likely to be extremely price sensitive. If and when costs become significantly higher in China, they can easily relocate. Already, they have diversified supply options. (See Gereffi, 1994.) 
The activities of the FIEs oriented toward the domestic market are rapidly improving the quality of goods sold within China. Indeed, FIE output is satisfying a demand for high quality consumer goods that was previously stifled. In this context, investment may permanently replace imports. In the first half of 1996, Chinese imports were up by 11.6 percent from the first half of 1995 and by 29 percent from the first six months of 1994 (when they had declined significantly in response to devaluation). These growth rates seem modest, particularly since China has been announcing reductions in NTBs and tariffs. Real appreciation was 35 percent over the two-year period to the beginning of 1996. This seems to indicate that there is a substantial lag in the response of imports to changes in currency values, that the price elasticity of demand for Chinese imports is relatively low, or that liberalization has been restrained and substantial nontariff barriers to imports remain.

As a result, the nominal value of the yuan is likely to remain stable, while domestic inflation, albeit at a lower rate, continues to cause real appreciation. This situation will continue to limit exports by domestic enterprises and possibly hold them to zero growth. The current exchange rate alignment thus appears relatively stable and should persist over the next few years. The exchange rate is not overvalued in the sense of threatening a foreign exchange crisis. On the contrary, the trade account is balanced and the inflow of foreign direct investment is significantly larger than the deficit in services: foreign exchange reserves continue to accumulate, possibly creating pressure for further appreciation. Over the long term, the relatively high real value of the yuan will discourage domestic firms from exporting and lead them to reorient their activities toward the domestic market. Trade ratios can be expected to decline to levels similar to those of the United States or Japan today.

It is probable that China will have difficulty in setting a stable exchange rate, whether or not present conditions persist. As the trade system is progressively unified and the exchange regime is opened, fluctuations in capital flows will create problems of exchange management. Since the inflow of investment to China is large, variations in the rate of flow are likely also to be large. Furthermore, one of the most prominent characteristics of the Chinese economy over the past seventeen years has been constant macroeconomic instability. Although the average rate of inflation over the period has been relatively low, money 
and credit have grown extremely rapidly, and the government has alternated between expansionary and contractionary policies. This persistent instability is plausibly connected to the weaknesses in the financial system described above. Although the system can sustain a tight monetary policy when danger signs are extremely clear, it seems incapable of generating a stable monetary policy when overall conditions are more ambiguous. Some observers believe that China is currently swinging back from a moderate contractionary phase to an expansionary phase. And underlying instability in monetary policy and overall macroeconomic policy make it extremely difficult to maintain a stable real exchange rate policy. It is unlikely that China could replicate the extremely focused and stable exchange rate policies that characterized the East Asian miracle economies during their export expansion phases. As a result, long-run incentives for exporters in China are unlikely to be as good as they were in those economies.

Indeed, China's experience has been very different from the exportled successes of Japan, Korea, and Taiwan. These economies significantly restricted foreign investment inflows when growth of manufactured exports was at its height; China has encouraged large inflows of foriegn direct investment. Japan, Korean, and Taiwan maintained stable currencies at levels that, if anything, were consistently undervalued; China's real exchange rate has fluctuated significantly, with a persistent tendency toward overvaluation (in regard to export competitiveness). Arguably, Taiwan and Korea were able to protect some sectors that faced competition from imports, while at the same time promoting a range of export sectors. ${ }^{72}$ In part, this was made possible by stable exchange rate policies, underpinned by restrictions on foreign capital inflows. China does not seem to have sufficient control over either capital inflows or exchange rates to carry out policies calibrated to specific sectors in this way. Finally, Japan, Korea, and Taiwan relied almost entirely on domestic firms to manufacture and to export commodities; China has largely relied on FIEs to produce exports, and

72. See Biggs and Levy (1991). It must be much harder for a large country to coordinate sectoral policies of any kind, and coordination is especially difficult in China because the government bureaucracy can be influenced by domestic interest groups and is prone to corruption. Consequently, China may be unable to replicate one of the key features of Japanese and Korean industrial policy: the strict coordination of external and domestic sectoral policies. 
virtually no domestic Chinese companies control significant export networks. Despite the superficial similarities in export growth, the institutional basis for foreign trade in China is completely different from that in Japan, Korea, or Taiwan.

\section{Tensions over Trade Liberalization}

Chinese policymakers do not yet seem to have made the difficult political decision to take practical steps toward substantial import liberalization in the short run. Yet current economic conditions argue strongly for more dramatic liberalization than China has yet undertaken. Import liberalization would ameliorate the Chinese version of the "Dutch disease," shifting the current account into deficit, pushing down the value of the currency, and to some extent restoring the competitiveness of Chinese exporters. There is certainly external pressure on China, manifested in the WTO and APEC, to accept a greater degree of liberalization. Indeed, Chinese exporters can only be assured of continued access to foreign markets if China joins the WTO and conforms to its fair trade principles. And there is strong domestic pressure from potential exporters and importers who are constrained from engaging in profitable trading activities. Finally, the continued accumulation of foreign exchange reserves not only increases external pressure for Chinese trade liberalization, but also provides a propitious cushion against its impact on the domestic economy.

On the other hand, there is also significant pressure to hold back from rapid liberalization. Central to this is concern about how such a strategy would affect existing SOEs and, indirectly, the financial system. With regard to the import-competing SOEs, this concern is naturally intensified by the present value of the Chinese currency. Indeed, China seems to have missed an opportunity to further liberalize its import regime during 1994, when currency values were low. ${ }^{73}$ As dis-

73. The government's response to the surge in food prices during the spring of 1994 encapsulates this point. Rather than electing to increase food grain imports substantially, Chinese policymakers decided to restrict certain kinds of grain exports, allowed the domestic price of food grains to jump significantly (to slightly above the world price, for the first time in memory), and announced modest subsidies to the agricultural sector. This reflects continued Chinese reluctance to rely on the world market for essential food supplies, particularly given difficult relations with the United States. Such fears of dependency, especially with respect to food and energy, may restrain China's progress 
cussed above, the effects of a dramatically increasing competition with the state sector might range from widespread bankruptcy to high unemployment and financial crisis. Across countries, financial crises are strongly associated with liberalization of the financial system and foreign exchange crises, and the association is likely to hold in China. In addition, revenue needs may obstruct progress toward rapid liberalization. China's fiscal condition has continued to deteriorate, despite important attempts at reform. The external sector is extremely lightly taxed, even though it is large and, until recently, was growing rapidly. The viability of highly differentiated tax provisions is increasingly doubtful: any given concessionary policy seems to undermine fiscal discipline as it is abused, expanded, and made the basis of competing claims for concessionary treatment. Probably the only solution is strict enforcement of uniform tax rates throughout the economy. This would almost certainly mean higher real taxes on trade. It would be preferable to concentrate tax increases on domestic economic activity, but China's continued institutional weakness may preclude this option. Finally, the economic problems associated with rapid liberalization reinforce political sentiments, such as rising nationalism and the desire to succeed at a "Korean-style" industrial policy. Proposals to foster priority (or " "pillar') industries, which inevitably imply some degree of import protection, are likely to be popular.

Hence the most likely outcome is a negotiated middle path of liberalization. The fact that SOEs are now concentrated in a limited number of industrial sectors suggests that China's trade policy can be adapted to protect existing interest groups, while yet liberalizing the overall import regime. This implies ongoing efficiency losses, since the protected sectors (including automobiles, chemicals, and refining) will be among the most distorted, but at least some of the momentum of the liberalization process will be maintained. In addition, some parts of the

toward greater openness. China has begun to increase its reliance on world markets in all sectors, but has also begun to adjust domestic policies to slow the growth of dependence. The hesitation to increase imports of food grain, for example, partly reflects the regional distribution of domestic surpluses. The adverse impact of such imports would fall most heavily on wheat growing regions in the north, which are poorer and have fewer alternative opportunities for employment than do the southern rice growing areas. And China has largely refused to allow Guangdong to procure either food or energy on world markets, even though this would make economic sense. If such policies continue, China's integration with world markets will proceed only at a moderate pace. 
rapidly expanding FIE industrial complex compete against imports. High quality domestic output will permanently reduce demand for certain kinds of imported goods, especially consumer goods. This could enable further gradual liberalization to take place, without undue dislocation.

Trade reform will also depend on the progress of internal reformin the tax and banking systems and in the SOE sector. The combination of reduced domestic competitiveness due to the relatively overvalued currency and the continued vulnerability of the SOEs and the state-run financial sector implies that liberalization is likely to be slow. Negotiations over China's membership in the WTO are currently stalled, due to Chinese unwillingness to offer practical counterproposals to the "road map" for membership advanced by the United States. While this tough stance undoubtedly reflects bargaining considerations, it almost certainly also reflects concern about the weakness of the state sector and the disruptions that might follow overly rapid liberalization.

\section{Regional Development}

The rapid growth of the coastal regions is creating new economic and political tensions in China. At the outset of reform, the coastal provinces were not uniformly richer than the inland provinces, and their prospects for success in world markets were extremely uncertain. But now the coastal provinces are almost invariably richer than the inland provinces, and their export success seems more predictable. It is difficult to defend preferential policies that consistently favor richer, better endowed segments of the population.

In recent years, Chinese leaders have repeatedly expressed their intention to abandon preferential policies toward the coastal regions in favor of purely sector-based industrial policies or preferential policies toward the inland regions. Nevertheless, growth in the coastal provinces has continued to outpace growth in inland areas. The share of total exports generated by coastal provinces increased from 84 percent in 1993 to 90 percent in the first six months of $1996 .{ }^{74}$ However, the

74. This was primarily due to the sharp decline of exports from the northeastern provinces of Heilongjiang and Jilin, which was related to the exhaustion of their exportable petroleum surpluses. However, it was also due to strong export growth in the central and northern coastal provinces. 
pattern of coastal growth is changing. Guangdong provides an outstanding illustration of the impact of congestion, rapid growth, and currency appreciation on a successful export base. During 1995, all of Guangdong's export growth came from FIEs. In the first half of 1996, FIE exports were up by 21 percent, while non-FIE exports were down by 38 percent. In essence, rising costs are forcing domestic firms out of the export business altogether. In fact, the growth rate of FIE exports in Guangdong is lower than in any of the other major coastal provinces, and the decline of non-FIE exports is greater. (Yet because of the larger share of FIE exports in Guangdong's total exports, the province has basically managed to maintain its share of national exports.) It appears that fundamental economic forces are pushing Guangdong out of its preeminent position in China's export drive.

The coastal provinces have real advantages of location and endowments of human and infrastructural capital. Therefore preferential policies alone cannot have a significant impact on regional growth. A serious response to China's regional problems will require an expensive program of accelerated infrastructure construction in inland regions, in particular, to improve transport networks. This strategy would only yield benefits over a fairly distant time horizon. Moreover, the high costs would probably lead the government to tax trade more heavily and use the money to fund increased inland infrastructure construction. Such policies would be suboptimal, but might represent the political equilibrium in the Chinese system.

\section{Technological Development}

The great imponderable factor is China's potential for rapid technological upgrade. In this respect, the country's size is undeniably an advantage. Per capita measures of educational attainment or technological capability in China are not particularly impressive, but in aggregate, the population possesses impressive absolute capabilities in science and technology. Despite its low per capita income, China exports satellite launch services (on a small scale), produces nuclear reactors and weapons, and reportedly has over a million computer programmers. China also appears to have substantial advantages based on the precocious development of heavy industry and R\&D activities within the framework of a planned economy. Positive assessments of China's 
technological capability take two forms in the literature. One stresses China's strengths in basic science and defense-related technologies and argues that the potential for industrial applications is great. In this vein, Chu-chia Lin proposes a model of economic cooperation between China and Taiwan, in which the former provides the basic science and technology, while the latter provides the manufacturing expertise. ${ }^{75}$

The other approach, developed by Mitsuhiro Seki, highlights Chinese skills in basic industrial technologies, as distinct from familiarity with assembly operations on the one hand and basic science and technology on the other. ${ }^{76}$ Masaru Yoshitomi explains: "The fundamental technologies . . . consist of casting, forging, plating, heat treatment, painting, machining, pressing, plastic molding, and other process technologies. . . . Most of the fundamental technologies are analog and mechanical [and] require a craftsman's skill, the learning of which takes years. The course of the industrial development of a country or a region tends to be strongly influenced by whether it possesses such fundamental technologies." 77 Since China does possess these capabilities, it has the potential for rapid technological upgrade and exceptionally broadbased industrialization.

The experience to date is rather mixed. By some measures, the share of capital-intensive manufacturing - in particular, machinery-in total Chinese exports is increasing alongside the share of labor-intensive manufacturing. Yet this impression tends to disappear when the data are examined more closely. Yoshitomi points out that within the machinery sector, China has revealed comparative advantage (at the threedigit level in the standard industrial classification) only in telecommunications equipment and household electrical appliances, both of which incorporate many labor-intensive assembly operations. Moreover, export processing plays a large role in their production. Since one of the chief characteristics of export processing is that it allows the separation and dispersal of labor-intensive stages of the supply chain, the skill composition of the finished product may not be a reliable guide to the nature of the activities actually performed in China. ${ }^{78}$

75. Lin (1994).

76. Seki (1994).

77. Yoshitomi (1996, pp. 15-16).

78. See Wall and Yin (1994). Yoshitomi also points out that high technology chemical exports are apparently dominated by a few traditional Chinese products, including explosives. 
China has recently attracted attention-both positive and negativefor beginning to supply components and subassemblies to aeronautics and aerospace producers in the United States. Even these achievements, however, are due largely to the attraction of access to the Chinese market and only indirectly to the cost-competitive provision of technological services. As one industry observer comments: "Offset requirements have now resulted in substantial off-shore manufacturing that is mistakenly attributed to the pursuit of lower labor rates. The often cited examples in the press of the placement of parts manufacturing in China by Boeing, McDonnell Douglas and various OEMs [original equipment manufacturers] are direct results of offset obligations." 79 Thus, at least through the early 1990s, it is difficult to find unambiguous evidence of technological upgrade in Chinese exports. Even when upgrade of exports is apparent, it is difficult to argue that China is closing the technological gap in terms of the technology embodied in exports.

Issues of technological upgrade also interact with regional issues. China's technological resources are highly concentrated in northern cities, especially Beijing and Shanghai. Yet the greatest expansion in exports has come from the southeastern coastal region, which had a relatively weak industrial and technological base as of the early 1980s. It is likely that any substantial upgrade of exports will coincide with a shift in the geography of exporting. In this respect, China's size will probably be determinative. On the one hand, its size may allow an extended quantitative expansion of exports of a given technological level. If factor markets are increasingly liberalized and labor migration continues to grow, the supply of labor-intensive manufactures may be very elastic for a long time. On the other hand, if regional barriers are significant and local cost pressures are highly divergent, China may behave essentially as an assemblage of regional economies, with different endowments and different comparative advantages.

\section{Competition for Export Markets}

In 1994, China produced 18 percent of all world exports of laborintensive products ${ }^{80}$ Despite the rapid growth and large share, prices

79. Latham (forthcoming).

80. According to the International Economic Databank at the Australian National University; see Findlay and Watson (1996, p. 13). 
of Chinese exports have risen slightly, not fallen. This may indicate a very high demand elasticity for China's manufactures, or it may simply be that producers in Hong Kong and Taiwan have exited from these sectors as production in China has come on stream, so that the net supply capacity has not increased. Chinese exports are clearly complementary to those from the more developed East Asian economies, such as Taiwan, Korea, and Japan.

However, China faces substantial competition from ASEAN countries in world markets. Not only is China's share of labor-intensive manufactures large, but the structure of revealed comparative advantage between China and at least some of the ASEAN countries is very similar. A comparison of correlation coefficients on revealed comparative advantage indexes in fifty-three labor-intensive products for China and twenty-five other countries finds that China has significant positive correlations with Korea, Thailand, Vietnam, and Indonesia. Elasticity of substitution among supplier countries is likely to be very high. ${ }^{81}$ Moreover, ASEAN countries-in particular, the populous "ASEAN four' (Indonesia, Thailand, Malaysia, and the Philippines)—-have been experiencing increasing world market shares in the same labor-intensive manufactures as China. The ASEAN four already export more than does China, and their export growth rates are similar, even after trade within ASEAN has been netted out. Thus the value of the ASEAN four's exports outside ASEAN was $\$ 44$ billion in 1987 and $\$ 108$ billion in 1993, while total Chinese exports in these years were worth $\$ 39$ billion and $\$ 92$ billion, respectively. China and ASEAN are both growing rapidly, exporting the same labor-intensive goods, and trying to upgrade their industrial structures.

China and ASEAN are trade partners as well as competitors, but their success in exporting to markets in developed countries means that the relative importance of their mutual trade has been declining steadily: the relative intensity of trade of China's exports to ASEAN has declined by more than half since 1980 . China would seem to have a better endowment of human capital than most of the ASEAN countries, except for Singapore and perhaps Malaysia. But in the absence of any clear indication that China is upgrading its exports more rapidly than are the

81. Boltho and others (1994, pp. 9-10). China also has significant positive correlations with Pakistan, India, Turkey, Egypt, Hungary, and Romania. 
ASEAN countries, it seems that their rivalry will continue. Indeed, the widely held perception of a few years ago that China was superior to ASEAN as a destination for technology-intensive export-oriented investment (for example, electronics) has now largely vanished.

To date, this implicit competition has had two important consequences. One is the response of the ASEAN countries to the "China challenge" - in essence, a "competitive unilateralism," in which individual countries undertake liberalization measures, particularly with respect to incoming foreign direct investment, in order to restore their competitive position relative to other potential host countries. The round of liberalization measures implemented in the early 1990s in order to win back foreign investors from China is a good example. ${ }^{82}$ The ASEAN response has also been an important factor pushing China to continue with liberalization.

The second important consequence is the development of the Asia Pacific Economic Cooperation process. APEC should be seen as an attempt to build on the existing framework of competitive unilateralism to create a systematic, though informal, process of interaction for mutual benefit. The challenge is to incorporate countries that are already open (such as Singapore and the United States); those that are liberalizing or are set to do so (such as Taiwan and Korea); those that are trying to combine protection and trade promotion (such as the ASEAN countries); and those that are struggling to end extreme protectionism (such as China). To this end, participants are offered both positive inducements and implicit threats. The main inducement is the ability to benefit from liberalization measures in member countries; the implicit threat is the danger of being left behind in a region that is rapidly expanding and liberalizing.

So long as overall world trade growth continues to be robust and export growth in China (and, to a lesser extent, the ASEAN countries) slows down, the adjustment required in the aggregate to accommodate these two growth areas should be feasible, with a modest amount of flexibility. The World Bank argues that there is room for the further expansion of labor-intensive exports from China, since there are still some sectors in which the Chinese presence is small ${ }^{83}$ China's com-

82. Tan (1994).

83. World Bank (1994). Boltho and others (1994) and Findlay and Watson (1996) also provide basically optimistic assessments. 
petitive challenge to ASEAN is likely to be moderated and contained by future trends. The ASEAN countries will find room in the expanding world market for labor-intensive manufactures to continue their recent phenomenal growth, while China will move to a slightly less steep growth trajectory. Today, China and the ASEAN four each account for about 3 percent of world exports. Assuming that world exports continue to grow at around 6 percent annually in real terms, real export growth at 10 percent annually in China and the ASEAN four would imply a 6 percent share of world exports for each in 2015, and real growth at 12 percent would imply an 8 percent share.

\section{Conclusion}

China has achieved export success through a combination of domestic economic reform and restructuring and the astute accommodation of opportunities created by East Asian economic restructuring and foreign investment. In some respects, the achievement is more limited than initially appears. The most successful export sectors are geographically concentrated and institutionally discrete. China is less open than trade ratios indicate for three independent reasons. First, because its purchasing power parity-adjusted GDP is so much larger than its exchange rate-converted GDP, trade ratios calculated with exchange rates can be misleading. Second, the degree of institutional separation between the domestic economy and the export sector remains substantial. Third, since so much export activity consists of processing imported materials, the share of in-country value added in exports is low. Thus activity in the export sector represents a smaller share of total national value added than might be supposed. Nonetheless, China's emergence as a major exporter in world markets is a real achievement.

The main thrust of China's external liberalization strategy is changing, and future trends are likely to be quite different from those of the past. A dualistic approach to trade reform made sense when export opportunities were geographically concentrated in the provinces around Hong Kong, and when foreign investors were the most attractive potential exporters. But today the challenge is to move nationwide liberalization a step forward. The transformation of Hong Kong from a manufacturing enclave into the center of a manufacturing network that 
extends throughout the province of Guangdong is now virtually complete. In the future, expanding and upgrading China's exports will require tapping the human capital located predominantly in the populous regions of northern and east-central China. Hence future export growth will not be determined by developments in Guangdong and Fujian to the same extent as past growth. Nor is it likely to be dominated by provincial export growth rates of over 30 percent (such as Guangdong and Fujian once achieved). Instead, future export growth is more likely to move close to (but still above) the 9 percent rate achieved by the rest of the country.

China's present path toward unifying the dualistic trade regime is unlikely to create a highly open trade system. This is largely the consequence of currency appreciation, brought on by massive capital inflows. Other recent policy choices point in the same direction; for example, scaling back the VAT rebate program, reducing concessionary measures for foreign investors, and taking a relatively hard-line position in international trade negotiations. Current policy choices, in conjunction with the underlying economic fundamentals, are slowing China's integration into the world economy.

The future is likely to bring a moderate deceleration in China's export growth. Currency appreciation is already slowing down exports, and Chinese policymakers do not seem ready yet to take the dramatic steps required to stem appreciation and accelerate import liberalization. In particular, the fragility of the state-run sector makes rapid liberalization less likely. And given China's poor fiscal position, the external sector is a tempting source of desperately needed revenues. Trade policy will focus much less on promoting exports; but genuine competitive ability will become more widespread. As part of this process, trade ratios will approach the norm for big countries. Later, as the pace of structural transformation and labor force growth slows, overall growth rates will also fall. China's export growth rates over the next twenty years may well be in the range of 10 to 12 percent per year, rather than the 17 percent annually achieved over the past decade.

Perhaps it is best to end on a note of uncertainty, however. Even though the present economic configuration makes liberalization more difficult for China, in some respects it also increases the ultimate benefits. Chinese policymakers are currently analyzing emerging economic trends. They may well decide against a scenario in which Chinese 
exports cede competitiveness to ASEAN exports and the Chinese share of world trade stabilizes or even declines. They may recognize that a major technological upgrade in China is probably contingent on rapid liberalization, and they may decide that this is also the only way to introduce real competition into a broad range of currently protected domestic sectors. They might further conclude that the recent slowdown in labor force growth permits more radical restructuring of existing firms than has so far been countenanced. Together, these factors may encourage China's policymakers to take some risks. Bold moves to liberalize would not be in keeping with past patterns of gradual and cautious reform. But it is important to recognize the feasibility of a policy package that would reverse many of the trends described and extrapolated above. And China will always retain the capacity to surprise the rest of the world. 


\section{Comments}

Nicholas R. Lardy: Barry Naughton's paper provides a very useful summary of China's external transformation during the reform era. Perhaps no other country has moved so rapidly from being a virtual nonparticipant in the international economy to being one of the top ten trading countries and one of the largest recipients of foreign direct investment in the world. One strength of the paper is that it clearly demonstrates the linkages between reform of China's domestic economy and changes in its trade and investment regimes. Another is that it gives considerable attention to the underlying demographic forces that have influenced the transition and will likely exert a significant influence on China's future growth path.

My comments fall into two areas. The first is the story of China's trade transformation. The paper portrays a strongly dualistic trade regime: an export promotion regime dominated by foreign-invested enterprises and an import substitution, or ordinary trade, regime populated largely by indigenous firms. While a strong element of dualism has emerged, I believe that the paper overstates the degree to which foreigninvested and indigenous firms operate under "entirely different... institutions and regulations." For example, the duty drawback system, which was introduced in the mid-1980s, is available to all exporters, not only foreign-invested firms. Similarly, many domestic firms have been given the right to import and export directly. And even if they frequently do not exercise this option, domestic producers of export goods increasingly have been able to choose between several competing foreign trade companies for their international transactions. That is a dramatic change from the prereform era, when firms producing export goods were forced to deal with a single, monopsonistic trading com- 
pany. In short, by the early 1990s, very few export products were still canalized. ' Finally, domestic firms also had access to swap markets, which provided foreign exchange at rates more favorable than the official exchange rate. Indeed, the principal participants in these markets were purely indigenous, not joint venture or wholly foreign-owned firms. ${ }^{2}$

These examples suggest that any dualism that has emerged in China's trading system reflects the varying ability of different categories of firms to exploit the opportunities created by the export promotion trade regime, rather than the deliberate creation of a separate trade regime for foreign-invested firms. As Naughton's paper shows, the export share of foreign-invested firms increased steadily in the decade 1985-95 and leaped upward in 1996, as exports of domestic firms shrank dramatically in absolute terms. He does not draw sufficient attention to a parallel dramatic rise in the share of exports produced by more entrepreneurial, nonstate firms, in particular, township and village enterprises. State-owned firms evince little ability to compete in international markets and thus have contributed relatively little to the growth of China's exports over the past decade.

The limited capacity of state firms to compete in international markets raises the question whether the paper is too optimistic about the ability of Chinese policymakers to liberalize the import regime while simultaneously protecting existing interest groups and avoiding "undue dislocation." This assessment is based on the observation that stateowned firms are concentrated in only a few sectors and now contribute only one-third of total manufacturing output.

Two important factors are overlooked in this analysis. The first is the continuing growth of employment in the state sector during the reform period. Naughton analyzes structural changes in the labor force, emphasizing the growing importance of employment in the nonagricultural sector and the declining share of new jobs in the urban public sector, especially after 1991. However, the growth of state sector employment and its continued importance, in urban areas in particular, is not discussed. In 1978 state sector employment stood at 72 million. At year-end 1994 it was at 112 million. More important from the perspec-

1. World Bank (1994, p. 28).

2. Lardy (1992b, p. 61). 
tive of the Chinese leadership, in 1994 two-thirds of the urban work force depended on the state for employment, a share that had remained almost unchanged for a decade.

The second factor is that a large portion of the roughly 3.5 trillion yuan in loans outstanding from China's four largest banks (all stateowned) at year-end 1995 is presumably held by state-owned firms. The presumption is quite strong, since about four-fifths of their outstanding loans have been extended to state-owned firms. Chinese banking authorities concede that 22 percent of these loans (representing 760 billion yuan) are nonperforming by Chinese standards, which are lax. Even if as much as half of this amount is ultimately recovered, the losses would be huge relative to either the capital or the reported profits of these banks. Losses of 380 billion yuan would be more than half again as great as their total capital; they would be equivalent to nineteen times the most recently reported annual profits of the banks as a group. In short, the restructuring of state-owned firms must be accompanied by a write-off of nonperforming loans and significant recapitalization of the banking system, the fiscal cost of which is likely to have an adverse effect on economic growth.

Thus the limits on import liberalization are perhaps more severe than the paper suggests. They are, I would judge, at the root of China's extreme reluctance to meet the current demands of the working party on China's membership in the World Trade Organization. It seems unlikely that China will accept an accession protocol that requires rapid liberalization of the import regime that protects state-owned industries. Rather, China appears determined to win maximum flexibility to control the timing of dismantling the barriers protecting its most sensitive sectors. 


\section{References}

Bélanger, Gérard, and others. 1994. "Eastern Europe: Factors Underlying the Weakening Performance of Tax Revenues.' Working Paper 104. Washington: International Monetary Fund (September).

Biggs, Tyler S., and Brian D. Levy. 1991. "Strategic Interventions and the Political Economy of Industrial Policy in Developing Countries.' In $R e$ forming Economic Systems in Developing Countries, edited by Dwight $\mathrm{H}$. Perkins and Michael Roemer. Cambridge, Mass.: Harvard Institute for International Development.

Boltho, Andrea, and others. 1994. "China's Emergence: Prospects, Opportunities, and Challenges.' Policy Research Working Paper 1339. Washington: World Bank (August).

China. General Administration of Customs (GAC). 1993. Zhonghua Renmin Gongheguo Haiguan Tongji Nianjian (China customs yearbook). Beijing: Zhongguo Haiguan Zongzhu.

Various years. China Customs Statistics. Hong Kong: Economic Information Agency.

China. State Statistical Bureau (SSB). 1990a. Quanguo Gesheng Zizhichu, Zhixiashi Lishi Tongji Ziliao Huibian (1949-1989) (Compilation of provincial historical statistics, 1949-1989). Beijing: Tongji Chubanshe.

- 1990b. Zhongguo Shangye Waijing Tongji Ziliao 1952-1988 (China commercial and external economic statistical materials 1952-1988). Beijing: Tongji Chubanshe.

1995a. 1994 Zhongguo Duiwai Jingji Tongji Nianjian (1994 China external economics statistical yearbook). Beijing: Zhongguo Tongji.

1995b. Zhongguo Tongji Nianjian (Statistical yearbook of China). Beijing: Zhongguo Tongji.

1996a. "Dangqian Woguo Laodong Shichang de Yanbian" (The evolution of current labor market conditions in China). Unpublished paper. State Statistical Bureau (October).

1996b. Zhongguo Tongji Zhaiyao (Statistical abstract of China). Beijing: Zhongguo Tongji.

Various years. Zhongguo Gongye Jingji Tongji Nianjian (China industrial economics statistical yearbook). Beijing: Zhongguo Tongji.

China Finance Association. 1994. Zhongguo Jinrong Nianjian (China finance annual). Beijing: Zhongguo Jinrong.

- Various years. Zhongguo Jinrong (China finance). Beijing: Zhongguo Jinrong.

China Statistical Information and Consultancy Center. Various years. China Monthly Statistics. Beijing: China Statistical Information and Consultancy Center. 
Crowley, James, Christopher Findlay, and Melissa Gibbs. 1991. "China's Export Marketing Performance and the Pressures for Reform." In Challenges of Economic Reform and Industrial Growth: China's Wool War, edited by Christopher Findlay. Sydney: Allen \& Unwin.

Dickson, Ian. 1996. “China's Steel Imports: An Outline of Recent Trade Barriers.' Working Paper 96-6. Adelaide: University of Adelaide, Chinese Economic Research Unit (July).

Findlay, Christopher, and Andrew Watson. 1996. "Economic Growth and Trade Dependency in China.' Paper prepared for the International Institute for Strategic Studies conference "China Rising: Interdependence and Nationalism.' San Diego, May 12-15.

Fukasaku, Kiichiro, and David Wall. 1994. China's Long March to an Open Economy. Paris: Organisation for Economic Co-operation and Development.

Gereffi, Gary. 1994. “The Organization of Buyer-Driven Global Commodity Chains: How U.S. Retailers Shape Overseas Production Networks.' 'In Commodity Chains and Global Capitalism, edited by Gary Gereffi and Miguel Korzeniewicz. Westport, Conn.: Greenwood Press.

Harrold, Peter. 1995. 'China: Foreign Trade Reform: Now for the Hard Part.' Oxford Review of Economic Policy 11(4): 133-46.

Howell, Jude. 1993. China Opens Its Doors: The Politics of Economic Transition. Boulder, Colo.: Lynne Rienner.

Jung, Woo S., and Peyton J. Marshall. 1985. "Exports, Growth and Causality in Developing Countries.' Journal of Development Economics 18(1): 1-12.

La Croix, Sumner J., Michael Plummer, and Keun Lee, editors. 1995. Emerging Patterns of East Asian Investment in China: From Korea, Taiwan, and Hong Kong. Armonk, N.Y.: M. E. Sharpe.

Lardy, Nicholas R. 1992a. "Chinese Foreign Trade." China Quarterly 131: 691-720.

- 1992b. Foreign Trade and Economic Reform in China, 1978-1990. New York: Cambridge University Press.

. 1995. "The Role of Foreign Trade and Investment in China's Economic Transformation." China Quarterly 144: 1065-82.

Latham, Richard. Forthcoming. "Chinese Defense Conversion and Restructuring: A Business Perspective.', In Mixed Motives, Uncertain Outcomes: Defense Conversion in China, edited by Jorn Brommelhorster and John Frankenstein. Boulder, Colo.: Lynne Rienner.

Lin, Chu-Chia. 1994. "Direct Foreign Investment, Industrial Integration, and Economic China: Taiwan's Point of View.' Paper prepared for University of California, Institute for Global Conflict and Cooperation conference on the China Circle. Hong Kong, December.

Naughton, Barry. 1992. "Macroeconomic Obstacles to Reform in China: The Role of Fiscal and Monetary Policy.' In The Aftermath of the 1989 Tian- 
anmen Crisis in Mainland China, edited by Bih-Jaw Lin. Boulder, Colo.: Westview.

1995. Growing Out of the Plan: Chinese Economic Reform, 19781993. New York: Cambridge University Press.

Noland, Marcus. 1996. "U.S.-China Economic Relations.” Asia Pacific Economic Cooperation Working Paper 96-6. Washington: Institute for International Economics (June).

Pei Changhong. 1996. "The Direction of Development of China's Foreign Trade System Reform during the Ninth Five Year Plan" (in Chinese). Guoji Maoyi (Intertrade) 5: 19-21.

Pomfret, Richard W. T. 1991. Investing in China: Ten Years of the Open Door Policy. Ames: Iowa State University Press.

Sachs, Jeffrey, and Wing Thye Woo. 1994. "Structural Factors in the Economic Reforms of China, Eastern Europe, and the Former Soviet Union." Economic Policy 18: 102-45.

Seki, Mitsuhiro. 1994. Beyond the Full-Set Industrial Structure: Japanese Industry in the New Age of East Asia. Tokyo: LTCB International Library Foundation.

Tan Kong Yam. 1994. "China and ASEAN: Competitive Industrialization through Foreign Direct Investment." Paper prepared for the University of California, Institute for Global Conflict and Cooperation conference on the China Circle. Hong Kong, December.

Thomas, Scott. 1991. "Apples and Oranges." Transition: The Newsletter About Reforming Economies 2(10): 7.

Tian Gang. 1994. "Shanghai's Role in China's Economic Development: 19791992," vol. 1. Ph.D. dissertation. Macquarie University, Sydney (February).

Wall, David, and Yin Xiangshuo. 1994. "Technology Development and Export Performance: Is China a Frog or a Goose?" Working paper 94-3. University of Sussex, Chinese Economy Programme (April).

Wang Yaping. 1996. "Analysis of Foreign Trade Trends in 1996 and Appropriate Policies" (in Chinese). Guoji Maoyi Wenti (Problems of international trade) 4: 21-25, 32 .

Watson, Andrew, Christopher Findlay, and Du Yintang. 1989. "Who Won the 'Wool War'? A Case Study of Rural Product Marketing in China.' China Quarterly 118: 213-41.

Wei, Shang-Jin. 1995. "The Open Door Policy and China's Rapid Growth: Evidence from City-Level Data." In Growth Theories in Light of the East Asian Experience, edited by Takatoshi Ito and Anne O. Krueger. Chicago: University of Chicago Press.

West, Loraine A. 1993. "Reform of China's Foreign Trade System and Pros- 
pects for Freer Trade." Staff Paper 69. Washington: U.S. Bureau of the Census, International Programs Center (October).

World Bank. 1994. China: Foreign Trade Reform. Washington: World Bank. 1996. The Chinese Economy: Fighting Inflation, Deepening Reforms. Washington: World Bank.

- Various years. World Development Report. New York: Oxford University Press.

Yoshitomi, Masaru. 1996. "The Comparative Advantage of China's Manufacturing in the 21 st Century." Paper prepared for the OECD Forum for the Future conference on "China in the 21 st Century: Long-Term Global Implications.' Paris, January 8-9.

Young, Alwyn. 1995. "The Tyranny of Numbers: Confronting the Statistical Realities of the East Asian Growth Experience.' Quarterly Journal of Economics 110(3): 641-80.

Zhang Gensheng. 1996. "Guangdongsheng Wailai Laodongli Liuru Qingkuang he Wenti" (Labor migration to Guangdong: trends and policies). Paper prepared for the conference on Rural-Urban Migration and the Floating Population. Beijing, June 26-28.

Zhu Linan. 1996. "Inward Foreign Investment and National Treatment" (in Chinese). Guoji Maoyi (Intertrade) 1: 27-29.

Zweig, David. 1995. “' 'Developmental Communities' on China's Coast: The Impact of Trade, Investment, and Transnational Alliances.' Comparative Politics 27(3): 253-74. 